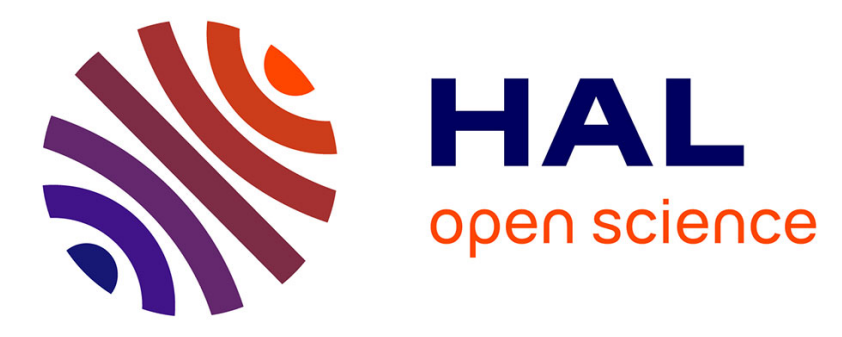

\title{
Use of Primary and Secondary Polyvinylamines for Efficient Gene Transfection
}

Mathilde Dréan, Antoine Debuigne, Cristine Gonçalves, Christine Jérôme, Patrick Midoux, Jutta Rieger, Philippe Guegan

\section{To cite this version:}

Mathilde Dréan, Antoine Debuigne, Cristine Gonçalves, Christine Jérôme, Patrick Midoux, et al.. Use of Primary and Secondary Polyvinylamines for Efficient Gene Transfection. Biomacromolecules, 2017, 18 (2), pp.440-451. 10.1021/acs.biomac.6b01526 . hal-01427315

\section{HAL Id: hal-01427315 https://hal.sorbonne-universite.fr/hal-01427315}

Submitted on 5 Jan 2017

HAL is a multi-disciplinary open access archive for the deposit and dissemination of scientific research documents, whether they are published or not. The documents may come from teaching and research institutions in France or abroad, or from public or private research centers.
L'archive ouverte pluridisciplinaire HAL, est destinée au dépôt et à la diffusion de documents scientifiques de niveau recherche, publiés ou non, émanant des établissements d'enseignement et de recherche français ou étrangers, des laboratoires publics ou privés. 


\title{
Use of Primary and Secondary Polyvinylamines
}

\section{for Efficient Gene Transfection}

\author{
Mathilde Dréan, ${ }^{\mathrm{a}, \mathrm{b}}$ Antoine Debuigne, ${ }^{* \mathrm{~b}}$ Cristine
}

Goncalves, ${ }^{\mathrm{c}}$ Christine Jérôme ${ }^{\mathrm{b}}$, Patrick Midoux, ${ }^{\mathrm{c}}$

Jutta Rieger,*a Philippe Guégan*a

a Sorbonne Universités, UPMC Univ Paris 06, CNRS, Institut Parisien de Chimie Moléculaire, Equipe Chimie des Polymères, 4 Place Jussieu, F-75005 Paris, France.

b Center for Education and Research on Macromolecules (CERM), Department of Chemistry, University of Liege (ULg), Sart-Tilman, Allée de la Chimie 3, Bat. B6a, B-4000 Liège, Belgium.

c Centre de Biophysique Moléculaire, UPR4301 CNRS, Rue Charles Sadron, 45071 Orléans Cedex 2, France 


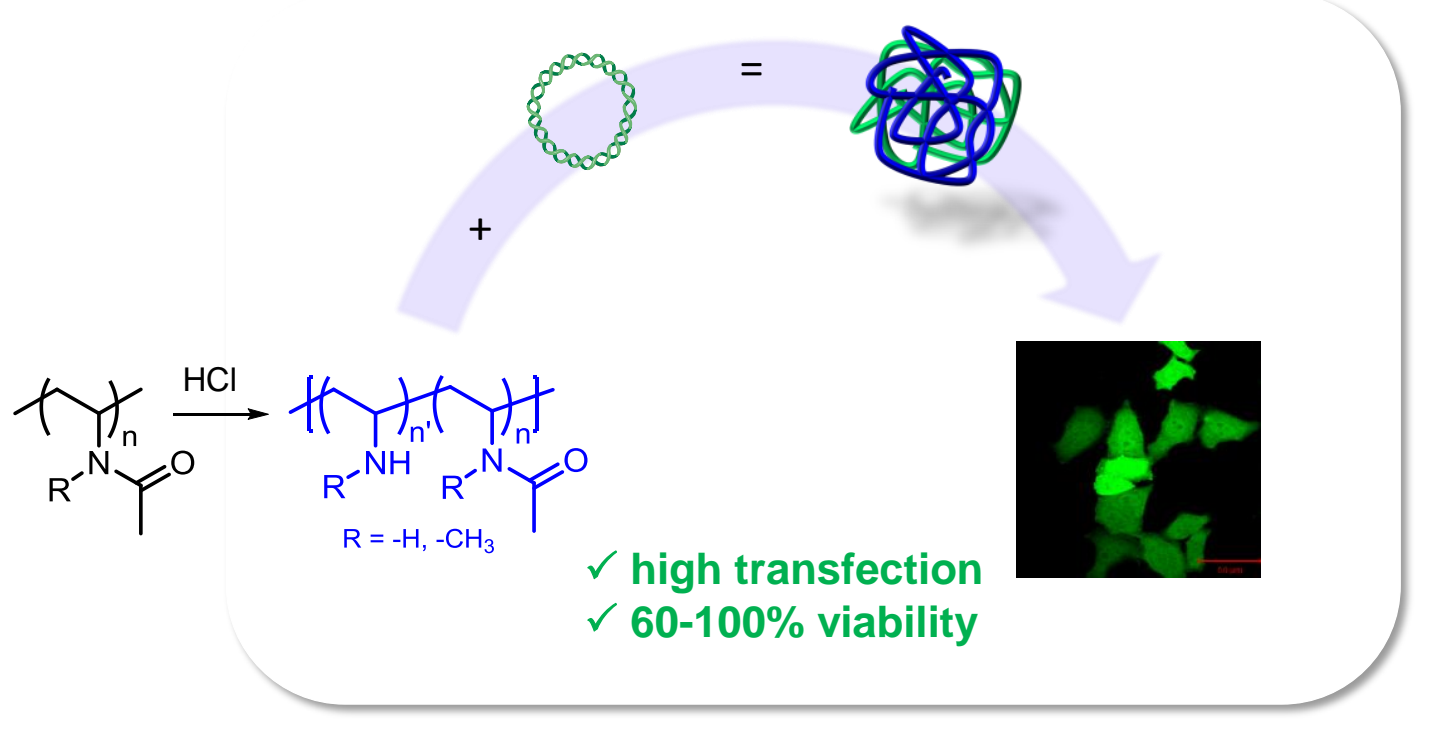

ABSTRACT

Gene transfection with polymeric carrier remains a challenge, particularly high transfection levels combined with low toxicity are hard to achieve. We herein revisit polyvinylamines, an old and neglected family of cationic polymers. They can be readily obtained by controlled hydrolysis of polyvinylamides prepared through (controlled) radical polymerization. A series of tailor-made and well-defined polyvinylamines bearing primary amino groups, and $\operatorname{poly}(\mathrm{N}$ methylvinylamine) bearing secondary amines, were evaluated for the transfection of cells with pDNA as a function of their molar mass, molar mass distribution and degree of deacetylation. Unexpected high transfection levels, in combination with low cytotoxicity were recorded for both series. Surprisingly, a great impact of the molar mass was observed for the primary amine polyvinylamine series, whereas the results were mostly independent on molar mass or dispersity for the polymer bearing secondary amine. It was further established that a certain percentage of acetamide groups increased the transfection level, while maintaining 
low cytotoxicity. These results highlight for the first time the real potential of polyvinylamines as gene carriers, and make these polymers very attractive for further development in gene therapy.

\section{Introduction}

Gene delivery aims at the introduction of genetic materials (DNA and RNA) in cells in order to modulate the cell activity, with a therapeutic objective in most cases. ${ }^{1}$ Efficient delivery is achieved through the use of vectors that prevent polynucleotides from degradation in physiological medium. ${ }^{2,} 3$ Viral vectors allow very efficient transfection and represent the leading strategy in the field. ${ }^{3,4}$ However, various drawbacks have been revealed, such as immune response, inflammation, random genomic integration and the limited size of the genetic material that can be transported..$^{4-6}$ Synthetic carriers have been considered in order to circumvent these limits. Among them, cationic polymers represent an important class of vectors that fulfil most requirements for gene delivery application. ${ }^{7}$ They allow to (i) easily complex nucleic acids into small particles thanks to electrostatic interactions, (ii) protect DNA or RNA against degradation by nucleases, and (iii) release them into the cell. ${ }^{8}$ Moreover, further advantages can be quoted such as the unlimited size of the genetic material that can be delivered, their easy production following the good manufacturing practice (GMP), and their low price production. Branched or linear polyethylenimine (bPEI or IPEI) is known as gold standard, thanks to its transfection efficiency. ${ }^{7,9,10}$ However, it suffers from a certain degree of cytotoxicity. Chemical modifications of the backbone have been largely investigated to improve both its cell viability and/or transfection efficiency. In this respect, the grafting of cyclodextrins, ${ }^{11,}{ }^{12} \mathrm{~N}$-ethylamine or $\quad \mathrm{N}$-dimethylethylamine, ${ }^{13}$ alkylcarboxylate, ${ }^{14}$ 
carboxyalkylate, ${ }^{15}$ sugars such as galactose ${ }^{16}$ or amino acids such as histidine ${ }^{17}$ to the amine functions was considered. The introduction of hydrophobic moieties was also studied through the partial acetylation of the amine function ${ }^{18-20}$ or the grafting of methylcarboxytrimethylene carbonate (MTC). ${ }^{21}$ Significant improvement of the biocompatibility of these vectors was reported, but the transfection efficiency remains low as compared to that reported for viruses. Following the development of PEI as potential gene carrier, ${ }^{22}$ various other polymer families have been tested such as polyamidoamine (PAMAM), ${ }^{23}$ chitosan, ${ }^{24} \operatorname{poly}(2-N-$ dimethylaminoethyl)methacrylate (PDMAEMA) $^{25}$ and poly( $\beta$-amino ester)s 26,27 . Surprisingly, the transfection ability of polyvinylamine (PVAm), an isomer of PEI, has been poorly studied so far. ${ }^{28}$ In 1999, PVAm with different molar masses and rather broad molar mass distributions were prepared via free radical polymerization (FRP) of $N$-vinylformamide (NVF) and subsequent alkaline hydrolysis of the amide functions. Condensation of a $6 \mathrm{~kb}$ plasmid by PVAm was observed to form nanoparticles (polyplexes) but no significant transfection was ensured when applied to Human Embryonic Kidney 293 cells (HEK 293). Since then, the use of PVAm as transfecting agent has been completely disregarded. ${ }^{26}$

A

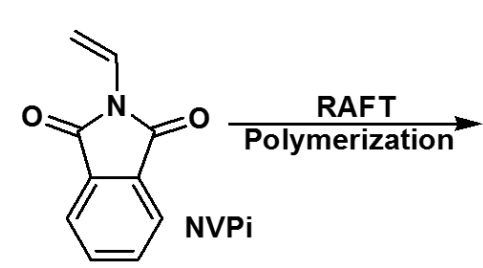<smiles>CC(CC(C)(C)C)C1NC1C</smiles><smiles>CCN1C(=O)c2ccccc2C1=O</smiles><smiles>CC(C)CC(C)C(C)N</smiles>

PVAm<smiles>[R]N(C=C)C(=O)[R]([H])(C)N</smiles>

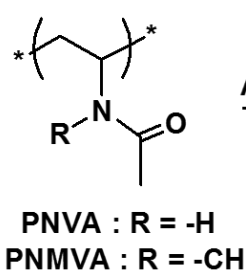

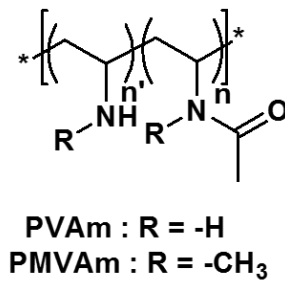

Figure 1. Synthesis of primary and secondary polyvinylamines. 
Given the importance of the macromolecular parameters for the transfection efficiency, which was demonstrated for several polymeric vectors, ${ }^{29-33}$ recent developments in controlled radical polymerization (CRP), particularly in the synthesis of well-defined polyvinylamines (Figure 1), could relaunch the research on PVAm for gene transfection. Primary PVAms with precise molar mass and low dispersity were notably obtained by reversible Addition-Fragmentation Transfer Polymerization (RAFT) of $N$-vinylphthalimide (NVPi) followed by the complete hydrazinolysis of the phthalimide groups (Figure 1 , route A).${ }^{34}$ On the other hand, the Organometallic Mediated Radical Polymerization (OMRP) of $N$-vinylacetamide (NVA) and $N$-methylvinylacetamide (NMVA) and subsequent mastered acidic hydrolysis of the pendant amide functions led to the controlled synthesis of, respectively, primary and secondary polyvinylamines bearing a defined amount of remaining pendant amides (Figure 1, route B). ${ }^{35}$ In the present work, we take benefit from the latest progress in CRP for further exploring the gene transfer performance of polyvinylamine derivatives. A large library of primary and secondary polyvinylamines, PVAms and PMVAms, respectively, with various molar masses and dispersities was prepared via FRP and CRP and tested for pDNA transfection. The cell viability was also systematically evaluated. Most of the controlled syntheses were achieved by OMRP, which gives access to primary and secondary polyvinylamines. Nevertheless, important information on the structure/activity relationship was also collected from polymers prepared by RAFT.

\section{Experimental part}

\subsection{Materials}


$N$-vinylacetamide (NVA) (> $98 \%$, TCI), $N$-vinylphthalimide (NVPi) (99\%, Acros Organics), cobalt(II) acetylacetonate (Co(acac)2) (97 \%, Aldrich), 2,2'-azobis(4-methoxy-2,4-dimethyl valeronitrile $)\left(\mathrm{V}-70, \mathrm{t}_{1} / 2=10 \mathrm{~h}\right.$ at $\left.30^{\circ} \mathrm{C}\right)(>98 \%$, Wako), 2,2'-azobis[2-methyl- $\mathrm{N}-(2-$ hydroxyethyl)propioamide] (VA-086, $\mathrm{t}_{1 / 2}=10 \mathrm{~h}$ at $\left.86^{\circ} \mathrm{C}\right)(>98 \%$, Wako), 2,2'-Azobis(2methylpropionitrile) (AIBN, $98 \%$, Aldrich), potassium ethyl xanthogenate (96\%, Aldrich), ethyl 2-bromopropanoate (99\%, Aldrich) and hydrazine monohydrate (98\%, Aldrich) were used as received. $N$-methylvinylacetamide (NMVA) (>98\% Aldrich) and vinyl acetate ( $>99$ $\%$, Aldrich) were purified by distillation under reduced pressure and degassed by freezedrying cycles under vacuum. Propanethiol (PrSH) (99\%, Aldrich), dichloromethane $\left(\mathrm{CH}_{2} \mathrm{Cl}_{2}\right)$ (p.a.), ethanol (p.a.), dimethylformamide (DMF) (p.a.) and methanol (MeOH) (p.a.) were degassed by bubbling argon for 30min. The alkyl-cobalt(III) adduct initiator ([Co(acac) $2_{2}$ $\left.\left(\mathrm{CH}(\mathrm{OAc})-\mathrm{CH}_{2}\right){ }_{4} \mathrm{R}_{0}\right] ; \mathrm{R}_{0}$ being the primary radical generated by 2,2 '-azo-bis(4-methoxy-2,4dimethyl valeronitrile) (V-70, Wako)) was prepared as described in the literature ${ }^{36}$ and stored as a $\mathrm{CH}_{2} \mathrm{Cl}_{2}$ solution at $-20^{\circ} \mathrm{C}$ under argon. Deuterated methanol (MeOD) and deuterated water $\left(\mathrm{D}_{2} \mathrm{O}\right)$ used for NMR characterization were ordered from Eurisotop. Dialysis membranes (cut-off, $1 \mathrm{kDa}$ ) were purchased from VWR. UV irradiation was performed with a Laboratory-UV-Reactor system 2 purchased from UV-Consulting Peschl. The photo-reactor is composed of a medium pressure mercury lamp TQ 150 (power input: $150 \mathrm{~W}$ ), a quartz immersion tube, a quartz cooling tube, power supply, reactor vessel with converter tube, discharge cock and sealing cap. The Acid Digestion Vessel $(23 \mathrm{~mL})$ used for hydrolysis reactions was purchased from Parr. Linear polyethyleneimine (IPEI) of $M_{\mathrm{w}}=22 \mathrm{kDa}$ was prepared as described. ${ }^{18}$

\subsection{Characterization}


$\underline{S E C}$. Number-average and weight-average molar masses $\left(M_{\mathrm{n}}\right.$ and $\left.M_{\mathrm{w}}\right)$ and molar mass distribution $(\bigoplus)$, of the polyvinylamides were determined by size exclusion chromatography (SEC) in dimethylformamide (DMF) containing $\mathrm{LiBr}(0.025 \mathrm{M})$ at $55^{\circ} \mathrm{C}$ (flow rate: 1 $\mathrm{mL} / \mathrm{min}$ ) with a Waters chromatograph equipped with three columns (Waters Styragel PSS gram $1000 \AA$ (x 2), $30 \AA$ ), a dual $\lambda$ absorbance detector (Waters 2487) and a refractive index detector (Waters 2414). Multi-angle laser light scattering (MALLS) measurements were performed with a Dawn Heleosapparatus from Wyatt Technology to determine the absolute molar masses $\left(M_{\mathrm{n}}{ }^{\mathrm{LS}}\right)$. Data were processed with Astra V Software (Wyatt technology). For each polymer, the $\mathrm{dn} / \mathrm{dc}$ value was measured by refractometry using a Wyatt OptilabrEX refractive index detector $(\lambda=658 \mathrm{~nm})$. A polystyrene calibration was also used to evaluate the molar mass distribution. After hydrolysis, the resulting PVAm, PMVAm were analyzed by SEC in water containing $\mathrm{NaCl}(0.1 \mathrm{M})$ and $\mathrm{TFA}(0.1 \% \mathrm{v})$ at $30^{\circ} \mathrm{C}$ (flow rate: $\left.1 \mathrm{ml} / \mathrm{min}\right)$ using a Waters SEC equipped with a pre-column (PSS NOVEMA Max analytical 10 micron $8.0 \mathrm{x}$ $50 \mathrm{~mm}$ ) and a linear column (PSS NOVEMA Max analytical linear S micron 8.0 x $300 \mathrm{~mm}$ ). Poly(2-vinylpyridine) (P2VP) standards were used to generate the calibration plot.

$\underline{N M R} .{ }^{1} \mathrm{H}$ NMR spectra were recorded in $\mathrm{D}_{2} \mathrm{O}$ (solvent) at $298 \mathrm{~K}$ with Bruker spectrometer (400 MHz) and treated with MestraNova software.

$\underline{E A}$. Elementary analyses were carried out by the Service de Microanalyse ICSN-CNRS (Gif sur Yvette, France) in order to determine the $\mathrm{C} / \mathrm{N}$ ratios in the copolymers before and after acidic treatment in order to evaluate the degree of deacetylation of the amide functions.

$\underline{I C P}$. Inductively coupled plasma (ICP) analyses were carried out by the Institut Malvoz de la Province de Liège (Liège, Belgium) in order to determine the quantity of residual cobalt polymers after acidic treatment $([\mathrm{Co}]<0.4 \mathrm{ppm})$. 
Titration. Aqueous solutions of polymers $(50 \mathrm{mg}$ in $10 \mathrm{~mL}$ of $1 \mathrm{~N} \mathrm{HCl}, \mathrm{PN} 255-\mathrm{Cs}$ and PM140-Fh, Table 1, entries 3 and 8) were titrated between $\mathrm{pH} 1$ and 12 using an automatic titrator (TIM 900, Radiometer Analytical) controlled by the TitraMaster 85 software. The polymer was first dissolved in $1 \mathrm{~N} \mathrm{HCl}$ and $0.5 \mathrm{~N} \mathrm{NaOH}$ was added progressively; each addition was performed after stabilization of the $\mathrm{pH}$ (SI Figure S1A). The method described by Colombani et al. ${ }^{37}$ was used to determine the protonation rate of these polyelectrolytes versus $\mathrm{pH}$. (SI Figure S1C). At physiological $\mathrm{pH}$, the protonation ratio of PVAm and PMVAm were around 0.74 and 0.79 , respectively. The apparent pKas of the same polymers were then determined following Borukhov et al. ${ }^{38}$ and found to be 10.6 and 12.4 , respectively (SI Figure S1D). The buffering capacity is the proton quantity required to decrease the $\mathrm{pH}$ by one unit. It can be determined from the slope of the titration curves between $\mathrm{pH}=6.5$ to 7.5 , the relevant $\mathrm{pH}$ range of endosome acidification in the cell. The buffer capacity determined as the reverse of the slope of the titration curves in Figure S1B (SI) was $0.13 \mathrm{~mL}$ and $0.09 \mathrm{~mL}$ for PVAm and PMVAm, respectively.

\subsection{Synthesis of PNVA by FRP.}

Following a procedure adapted from reference ${ }^{39}$, NVA $(4.0 \mathrm{~g}, 47 \mathrm{mmol})$ and V70 $(320 \mathrm{mg}$, $1.0 \mathrm{mmol})$ were placed under argon and dissolved in degassed methanol $(6 \mathrm{~mL})$. The reaction was heated at $30^{\circ} \mathrm{C}$ for 45 min (total monomer conversion measured by ${ }^{1} \mathrm{H}$ NMR in $\mathrm{D}_{2} \mathrm{O}$ by integrating the signals of the methine proton of the monomer (at $6.78 \mathrm{ppm}, 1 H$ ) and the methyl protons (1.9 to $2.0 \mathrm{ppm}, 3 H$ ) for both the monomer and the polymer, conv. $=35 \%$ ). The polymer was purified by precipitation in acetone, filtrated and dried under vacuum before dissolution in water and dialysis (membrane cut off $1 \mathrm{kDa}$ ) against pure water for two days with regular water exchanges. ${ }^{40}$ After lyophilization, PNVA was collected as a white solid and characterized by ${ }^{1} \mathrm{H}$ NMR in $\mathrm{D}_{2} \mathrm{O}(c f$. SI, Figure S2), and SEC-MALLS in DMF (dn/dc 
PNVA in DMF $=0.060, M_{\mathrm{n}, \mathrm{SEC} \text { DMF MALLS }}=58.3 \mathrm{~kg} / \mathrm{mol}, M_{\mathrm{n}, \mathrm{SEC} \text { DMFcal PS }}=31.3 \mathrm{~kg} / \mathrm{mol}, \bigoplus_{\mathrm{SEC} \text { DMFcal }}$ $\mathrm{PS}=1.69) .($ Table 1, entry 1$)$

\subsection{Synthesis of PNVA by photo-initiated OMRP.}

Following a procedure adapted from reference ${ }^{35}, \mathrm{Co}(\mathrm{acac})_{2}(204 \mathrm{mg}, 0.79 \mathrm{mmol})$, VA-086 (460 mg, $1.6 \mathrm{mmol})$ and NVA (15.0 g, $176 \mathrm{mmol})$ were added in a reactor designed for photochemistry (Laboratory-UV-Reactor system 2 purchased from UV-Consulting Peschl), an immersion-well reactor in which the lamp is surrounded by the solution in a quartz tube. The medium is degassed by three vacuum/argon cycles before addition of degassed $\mathrm{MeOH}$ (15 $\mathrm{mL}$ ). The reactor was maintained at $0^{\circ} \mathrm{C}$ in an ice-bath and the mixture was irradiated with an UV lamp (TQ 150 with a power input at $150 \mathrm{~W}$ ) for $4 \mathrm{~h}$ at $0^{\circ} \mathrm{C}$. After the irradiation was stopped, the medium was allowed to return to room temperature $\left(\sim 20^{\circ} \mathrm{C}\right)$ and the polymerization proceeded for $7 \mathrm{~h} 30$. A sample was picked out of the reactor, quenched by TEMPO, and used for determining the conversion by ${ }^{1} \mathrm{H}$ NMR (23\%) and the molar mass of the polymer by SEC analyses. In order to quench the reaction as reported elsewhere, ${ }^{40}$ degassed 1-propanethiol $(1.40 \mathrm{~mL}, 15.8 \mathrm{mmol})$ was added with a syringe under inert atmosphere to the reaction medium which became instantaneously black. The medium was stirred overnight at room temperature. The reaction medium was eluted through a celite pad allowing removing black residues. The polymer was then recovered by several precipitations in acetone and dried under vacuum. The polymer was further purified by dialysis against water for two days. After lyophilisation, an off-white solid was obtained and characterized by SEC, NMR and ICP. $\left(\mathrm{dn} / \mathrm{dc}_{\mathrm{PNVA}}\right.$ in DMF $=0.060, M_{\mathrm{n}, \mathrm{SEC} \text { DMF MALLS }}=56.3 \mathrm{~kg} / \mathrm{mol}, M_{\mathrm{n}, \mathrm{SEC}}$ DMF cal PS $=48.1 \mathrm{~kg} / \mathrm{mol}, \bigoplus_{\mathrm{SEC}}$ DMF cal PS $=1.18, M_{\mathrm{n}, \mathrm{SEC}} \mathrm{H} 2 \mathrm{O}$ cal P2VP $=31.0 \mathrm{~kg} / \mathrm{mol}, \bigoplus_{\mathrm{SEC}} \mathrm{H} 2 \mathrm{O}$ cal P2VP $=$ 1.27) (Table 1, entry 4). Similar experiments were carried out varying the $[\mathrm{NVA}] /[\mathrm{VA}-$ $86] /\left[\mathrm{Co}(\mathrm{acac})_{2}\right]$ ratio and the reaction time, as reported in Table 1. 


\subsection{Synthesis of PNMVA by FRP.}

Following a procedure adapted from reference ${ }^{39}$, V70 (416 mg, $\left.1.35 \mathrm{mmol}\right)$ was placed under argon in a flask, dissolved in degassed methanol $(14 \mathrm{~mL})$ followed by addition with a syringe of distilled and degassed NMVA (14.0 mL, $13.4 \mathrm{~g}, 135 \mathrm{mmol})$. The reaction mixture was then heated at $30^{\circ} \mathrm{C}$ for $4 \mathrm{~h}$ (total monomer conversion measured by ${ }^{1} \mathrm{H}$ NMR in $\mathrm{D}_{2} \mathrm{O}$ by integrating the signals of the methine proton of the monomer (at 7.04 and $7.35 \mathrm{ppm}, 1 \mathrm{H}$ ) and the $N$-methyl protons region (2.8 to $3.0 \mathrm{ppm}, 3 H$ ) for both the monomer and the polymer, conv. $=14 \%)$. The polymer was then purified by precipitation in diethyl ether, filtrated and dried under vacuum before dissolution in water and dialysis (membrane cut off $1 \mathrm{kDa}$ ) against water for two days. After lyophilization, PNMVA was collected as a white solid and characterized by ${ }^{1} \mathrm{H}$ NMR in $\mathrm{D}_{2} \mathrm{O}(c f$. SI, Figure S2), and SEC-MALLS in DMF (dn/dc PNMVA in DMF $=0.071, M_{\mathrm{n}, \mathrm{SEC}}$ DMFMALLS $=13.7 \mathrm{k} \mathrm{g} / \mathrm{mol}, M_{\mathrm{n}, \mathrm{SEC} \text { DMFcal PS }}=17.8 \mathrm{~kg} / \mathrm{mol}, \bigoplus_{\mathrm{SEC} \text { DMF cal PS }}=$ 1.79). (Table 1 , entry 8 ). Similar experiments were carried out varying the $[\mathrm{NMVA}] /[70]$ ratio and the reaction time, as reported in Table 1.

\subsection{Synthesis of PNMVA by OMRP.}

Following a procedure adapted from reference ${ }^{35}$, a solution of alkyl-cobalt (III) initiator $\left(\left[\mathrm{Co}(\mathrm{acac})_{2}-\left(\mathrm{CH}(\mathrm{OAc})-\mathrm{CH}_{2}\right)_{\sim 4} \mathrm{R}_{0}\right]\right.$ in $\left.\mathrm{CH}_{2} \mathrm{Cl}_{2}\right)(1.30 \mathrm{~mL}$ of a $0.15 \mathrm{M}$ stock solution, 0.195 mmol) was introduced in a flask under argon and evaporated to dryness under reduced pressure at room temperature. Distilled NMVA $(6.0 \mathrm{~mL}, 58 \mathrm{mmol})$ was added under argon into the flask and the polymerization mixture was stirred at $40^{\circ} \mathrm{C}$. After $16 \mathrm{~h}$, the polymerization was stopped by addition of 1-propanethiol $(0.35 \mathrm{~mL}, 3.9 \mathrm{mmol})$ and the medium became instantaneously dark black. Stirring was maintained overnight at room temperature. After elution of the polymer solution through a celite pad for removing the black matter, the polymer was precipitated in diethylether, filtered and dried. A second precipitation 
was performed in $\mathrm{Et}_{2} \mathrm{O}$ after solubilizing the polymer in $\mathrm{MeOH}$. Finally, the polymer was purified by dialysis against water for two days and was collected as an off-white solid after lyophilisation. The resulting PNMVA was analyzed by SEC and ${ }^{1} \mathrm{H}$ NMR. (dn/dc PNMVA in DMF $=0.071, M_{\mathrm{n}, \mathrm{SEC}}$ DMF MALLS $=30.8 \mathrm{~kg} / \mathrm{mol}, M_{\mathrm{n}, \mathrm{SEC} \text { DMF cal PS }}=21.6 \mathrm{~kg} / \mathrm{mol}, \bigoplus_{\mathrm{SEC} \text { DMF cal PS }}=1.12$, $M_{\mathrm{n} \text { SEC H2O cal P2VP }}=3.5 \mathrm{~kg} / \mathrm{mol}, \bigoplus_{\mathrm{SEC} \mathrm{H} 2 \mathrm{O} \text { cal P2VP }}=1.8$, Table 1 , entry 13$)$. Similar experiments were carried out varying the initial $[\mathrm{NMVA}] /\left[\mathrm{RCo}(\mathrm{acac})_{2}\right]$ molar ratio and the reaction time in order to produced PNMVA of different molar masses as reported in Table 1.

\subsection{Synthesis of the polyvinylamine derivatives by hydrolysis of the polyvinylacetamide precursors.}

Following a procedure adapted from reference ${ }^{39}, 400 \mathrm{mg}$ of poly $(N$-methylvinylacetamide $)$ (PNMVA) were dissolved in $\mathrm{HCl} 6 \mathrm{~N}(5.5 \mathrm{~mL})$. The resulting polymer solution $(7 \% \mathrm{w} / \mathrm{v})$ was then placed in an Acid Digestion Parr Vessel and heated at $120^{\circ} \mathrm{C}$ for $64 \mathrm{~h}$ (harsh conditions). After cooling, the solution was dialyzed against pure distilled water for one night, and water was exchanged twice. During the last two hours of dialysis, the $\mathrm{pH}$ was maintained at 7 ( $\mathrm{pH}$ controlled with $\mathrm{pH}$ meter and adjusted by addition of $\mathrm{NaOH} 0.1 \mathrm{~N}$ or $\mathrm{HCl} 1 \mathrm{~N}$ ). The polymer was recovered upon lyophilization. The polymer was analyzed by ${ }^{1} \mathrm{H} N M R$ in $\mathrm{D}_{2} \mathrm{O}$ (cf. SI, Figure S2), IR and EA. In addition, the hydrolysis of PNVA was performed under milder conditions $\left(5 \% \mathrm{w} / \mathrm{v}, \mathrm{HCl} 2 \mathrm{~N}, 120^{\circ} \mathrm{C}, 14 \mathrm{~h}\right)$ according to reference. ${ }^{39}$ Finally, partially deacetylated PMVAms, $\mathrm{P}\left(\mathrm{MVAm}-\mathrm{co}\right.$-NMVA), were obtained using $\mathrm{HCl} 3 \mathrm{~N}$ at $100^{\circ} \mathrm{C}$ for different periods according to kinetics performed by Buys. ${ }^{41}$ The determination of the percentage of hydrolysis for each polymer was achieved using the elementary analysis (EA). The method was based on the $\mathrm{C} / \mathrm{N}$ ratio in the polymer before and after acidic treatment rather than on absolute mass percentage of $\mathrm{C}$ and $\mathrm{N}$ in order to prevent mistakes coming from the hydroscopic character of the polymers (SI Table A1). 


\subsection{Synthesis of $O$-ethyl-S-(1-ethoxycarbonyl) ethyl dithiocarbonate (CTA-X1).}

The synthesis of $O$-ethyl-S-(1-ethoxycarbonyl) ethyl dithiocarbonate was performed according to reference ${ }^{42}$ by mixing ethyl 2-bromopropionate $(2.0 \mathrm{~mL}, 2.8 \mathrm{~g}, 15 \mathrm{mmol})$ in ethanol $(18 \mathrm{~mL})$ and adding portion-wise potassium ethyl xanthogenate (2.03 g, $12.7 \mathrm{mmol})$ at $0^{\circ} \mathrm{C}$. Then the reaction took place at room temperature $\left(\sim 20^{\circ} \mathrm{C}\right)$ overnight. After complete conversion, the product was extracted by $\mathrm{Et}_{2} \mathrm{O}$ / pentane (2/1), washed with $\mathrm{H}_{2} \mathrm{O}$ and dried over $\mathrm{MgSO}_{4}$. The solvents were removed under reduced pressure in order to obtain the desired product as an orange liquid. The product was analyzed by ${ }^{1} \mathrm{H} \mathrm{NMR}\left(\mathrm{CDCl}_{3}, 300\right.$ MHz): $\delta 1.28$ ppm (t, 3H, $J=7.1 \mathrm{~Hz}), 1.41 \mathrm{ppm}(\mathrm{t}, 3 \mathrm{H}, J=7.1 \mathrm{~Hz}), 1.57 \mathrm{ppm}(\mathrm{d}, 3 \mathrm{H}, J=7.3$ Hz), 4.20 ppm (q, 2H, $J=7.1 \mathrm{~Hz}), 4.38 \mathrm{ppm}(\mathrm{q}, 1 \mathrm{H}, J=7.3 \mathrm{~Hz}), 4.64 \mathrm{ppm}(\mathrm{q}, 2 \mathrm{H}, J=7.1$ $\mathrm{Hz}), 97 \%$ yield, $>98 \%$ pure.

\subsection{Synthesis of PNVPi by RAFT polymerization.}

Following a procedure adapted from references ${ }^{34,43,44}$, NVPi (5.00 g, $\left.28.9 \mathrm{mmol}\right)$ was dissolved in a solution of DMF (14 mL), containing AIBN (23.5 mg, $0.143 \mathrm{mmol})$ and CTAX1 (132 mg, $0.594 \mathrm{mmol})$ (Table 3, entry 2). The mixture was place in a flask equipped with a magnetic stirring bar and the solution was degassed by Argon bubbling for $30 \mathrm{~min}$. Thereafter the polymerization was performed at $60^{\circ} \mathrm{C}$ for $24 \mathrm{~h}$. After cooling, the polymer was centrifuged to remove a black precipitate, precipitated in $\mathrm{Et}_{2} \mathrm{O}$, filtrated and dried under vaccum. The resulting PNVPi was analyzed by SEC and ${ }^{1} \mathrm{H}$ NMR, $\mathrm{dn} / \mathrm{dc}$ PNVPi in DMF $=0.13$, $M_{\mathrm{n}}$ SEC DMF LS $=12.9 \mathrm{~kg} / \mathrm{mol}, M_{\mathrm{n} \text { SEC DMF cal PMMA }}=4.6 \mathrm{~kg} / \mathrm{mol}, \bigoplus_{\mathrm{SEC}}$ DMF cal PS $\left.=1.6\right)$. Similar experiments were carried out varying the initial $[\mathrm{NVPi}] /[\mathrm{AIBN}] /[\mathrm{CTA}-\mathrm{X} 1]$ molar ratio and the reaction time in order to prepare PNVPi of different molar masses (SI, Table S2). 


\subsection{Hydrazinolysis of PNVPi.}

Following a procedure adapted from references ${ }^{34,43,44}, 4.5 \mathrm{~g}$ of PNVPi (26 mmol of NVPi) was dissolved in 1,4-dioxane/MeOH 1/2 (100 mL) and hydrazine monohydrate $(31.0 \mathrm{~mL}$, $0.636 \mathrm{~mol}$ ) was added under inert atmosphere. The reaction was performed at $65^{\circ} \mathrm{C}$ overnight under stirring. After cooling, the solvents were removed under reduced pressure. In order to obtain the desired polyvinylamine, the resulting solution was treated with acid $(\mathrm{HCl} 6 \mathrm{~N})$. The final polymer was dialysed against pure water for two days, maintaining the final water at $\mathrm{pH}$ 7. The aqueous solution was lyophilized. The resulting PVAm was analyzed by ${ }^{1} \mathrm{H}$ NMR in $\mathrm{D}_{2} \mathrm{O}$ and EA. The ${ }^{1} \mathrm{H}$ NMR spectra showed the absence of residual 2,3-dihydro-1,4phthalazinedione, a side product of the hydrazinolysis. Hydrazinolysis degrees were determined by EA using the $\mathrm{C} / \mathrm{N}$ content ratio in the polymer before and after acidic treatment (SI Table S1, entries 7 to 9).

\subsection{Acetylation of PVAm.}

Following a procedure adapted from reference ${ }^{45}$, PVAm $\left(\mathrm{PN} 170-\mathrm{R}, M_{\mathrm{n}}=7.2 \mathrm{~kg} / \mathrm{mol}, D P_{\mathrm{n}}=\right.$ 167, $0.10 \mathrm{~g}, 2.3 \mathrm{mmol}$ of VAm, $c f$. Table S2), prepared by hydrazinolysis of PNVPi, was dissolved in $0.40 \mathrm{~mL}$ of distilled water, and triethylamine $(0.40 \mathrm{~mL}, 2.9 \mathrm{mmol})$ and then methyl acetate $(0.1 \mathrm{~mL}, 1.3 \mathrm{mmol})$ were added under inert atmosphere. The reaction was performed at $30^{\circ} \mathrm{C}$ for one night. The polymer was dialyzed against pure water for two days, maintaining the final water at $\mathrm{pH}$ 7, and then lyophilized. The resulting PVAm was analyzed by ${ }^{1} \mathrm{H}$ NMR in $\mathrm{D}_{2} \mathrm{O}$. A degree of acetylation of $50 \%$ was determined by elemental analysis (EA). The method was based on the determination of the $\mathrm{C} / \mathrm{N}$ ratio in the polymer before and after acidic treatment rather than on absolute mass percentage of $\mathrm{C}$ and $\mathrm{N}$ to take in account the hygroscopic character of the polymers that may alter the deacetylation degree determination. 


\subsection{Plasmids.}

pCMV-luc (pTG11033, 9514 bp, Transgene S.A., Strasbourg, France) was a plasmid DNA encoding the firefly luciferase (luc) gene under the control of the human cytomegalovirus (CMV) promoter. pCMV-EGFP (5130 bp) was a plasmid DNA encoding the jellyfish Aequorea victoria enhanced green fluorescent protein (EGFP) under the control of the human cytomegalovirus (CMV). Supercoiled plasmid was isolated from Escherichia coli DH5a super competent bacteria (Invitrogen, Cergy Pontoise, France) by alkali lysis and purification with QIAGEN Mega Kit Endotoxin free Plasmid (Qiagen, Courta-boeuf, France).

\subsection{Polyplexes.}

Polyplexes were prepared at various polymer/DNA weight ratios (WR) in HEPES $10 \mathrm{mM}$, pH 7.4. The proper amount of polymers was added to the pDNA solution $(2.5 \mu \mathrm{g}$ in $32.5 \mu \mathrm{L}$ of HEPES, $1 \mathrm{mg} / \mathrm{mL}$ ) and vortexed for $4 \mathrm{~s}$. Typically, for a WR of $3,15 \mu \mathrm{L}$ of a $0.5 \mathrm{mg} / \mathrm{mL}$ solution of the polymer in HEPES (corresponding to $7.5 \mu \mathrm{g}$ of polymer) was added to $32.5 \mu \mathrm{L}$ $(2.5 \mu \mathrm{g})$ of the pDNA solution (at a concentration of $1 \mathrm{mg} / \mathrm{mL}$ ). After $30 \mathrm{~min}$ at room temperature, the solutions containing polyplexes were adjusted to a total volume of $500 \mu \mathrm{L}$ using culture medium supplemented with $10 \%$ FBS (MEM for HeLa and 16HBE, DMEM for C2C12 and RPMI 1600 for DC2.4).

\subsection{Size and $\zeta$ potential measurements of polyplexes.}

Polyplexes were prepared as above with $2 \mu \mathrm{g}$ pDNA in a total volume of $200 \mu \mathrm{L}$ of $10 \mathrm{mM}$ HEPES, pH 7.4. The size of polyplexes measured by dynamic light scattering (DLS) and $\zeta$ potential measurements were performed by using SZ-100 Nanopartica (Horiba, Les Ulis, 
France). Samples were illuminated with a $633 \mathrm{~nm}$ laser, and the intensities of scattered light at an angle of $173^{\circ}$ and $15^{\circ}$ were measured using an avalanche photodiode, respectively for size measurement and zeta potential determination. The z-average hydrodynamic diameter $\left(D_{h}\right)$ of the samples was calculated automatically.

\subsection{Gel retardation assay.}

Polyplexes were freshly prepared at various polymer/pDNA weight ratios (WR) in a solution of HEPES $10 \mathrm{mM}$ pH 7.4. Samples of $20 \mu \mathrm{L}$ were loaded onto $0.9 \%$ agarose gel containing EtBr $(0.3 \mathrm{mg} / \mathrm{mL})$ in a Tris-borate-EDTA buffer, $\mathrm{pH} 8.6(95 \mathrm{mM}$ Tris, $89 \mathrm{mM}$ boric acid, 2.5 mM EDTA and $10 \mathrm{mM}$ DTT, $\mathrm{pH}$ 8.6) and ran at $100 \mathrm{~V}$ for $45 \mathrm{~min}$. The gels were analyzed using the Azure ${ }^{\mathrm{TM}}$ Biosystem c600 to visualize pDNA.

\subsection{Determination of the phosphate/nitrogen $\mathbf{N} / \mathbf{P}$ molar ratio.}

The mole number of protonable nitrogen atoms at $\mathrm{pH} 7.4$ per $\mathrm{g}$ polymer $\left(N^{N+}\right.$ in $\left.\mathrm{mol} / \mathrm{g}\right)$ was calculated taking into account the deacetylation degree of the polymers, reported in Tables 1 and 2), the molar mass of each monomer unit and the molar fractions of the monomer units containing nitrogen atoms protonable at $\mathrm{pH}$ 7.4, i.e. VAm and MVAm (eq. 1).

$N^{N+}=\frac{\left(F_{V A m}+F_{M V A m}\right)}{\sum \mathrm{M}_{\mathrm{i}} F_{\mathrm{i}}}$

,where $\mathrm{M}_{\mathrm{i}}$ and $\mathrm{F}_{\mathrm{i}}$ correspond to the molar mass and the molar fraction of the comonomer units in the copolymer, i.e. VAm and MVAm.

The mole number of charged phosphate per g of pDNA $\left(N^{P_{-}}\right.$in mol/g) was determined according to equation 2 . 
$N^{P_{-}}=\frac{1}{\mathrm{MM}_{\mathrm{bp}} / 2}=3.058 \times 10^{-3} \mathrm{~mol} / \mathrm{g}$

, where $\mathrm{MM}_{\mathrm{bp}}$ corresponds to the mean molar mass of a base pair $\left(\mathrm{MM}_{\mathrm{bp}}=654 \mathrm{~g} / \mathrm{mol}\right)$

The N/P ratio is calculated based on equation 3 and takes into account the polymer/pDNA weight ratio (WR, reported in Tables 4 and 5).

$$
\frac{N}{P}=\frac{N^{N+}}{N^{P+}} \times W R
$$

\subsection{Cell culture.}

Human epithelioid cervix carcinoma cells (HeLa cells; CRL1772, C2C12, Rockville, MD, USA) were cultured in MEM medium supplemented with $10 \% \mathrm{FBS}, 100 \mathrm{U} / \mathrm{mL}$ penicillin, $100 \mathrm{mg} / \mathrm{mL}$ streptomycin, $1 \%$ non-essential amino acid, and $1 \%$ GlutaMAX $^{\mathrm{TM}}$. Cells were maintained at $37^{\circ} \mathrm{C}$ in a humidified $5 \% \mathrm{CO}_{2}$ atmosphere. Cells were checked for mycoplasma presence using the MycoAlert1 Mycoplasma Detection Kit (Lonza, Levallois Perret, France).

\subsection{Transfection and luciferase gene expression measurement.}

One day before transfection, cells were seeded in a 24 -well plate at a density of $1.5 \times 10^{5}$ cells per well in $1 \mathrm{~mL}$ in culture medium. After removing the culture medium, they were incubated with freshly made polyplexes $\left(500 \mu \mathrm{L}, 2.5 \mu \mathrm{g}\right.$ DNA) for $4 \mathrm{~h}$ at $37^{\circ} \mathrm{C}$. Then, the medium was removed and replaced with fresh complete medium. The Luciferase activity was measured 48h after transfection by using a luminometer (LUMAT LB 9507). Then the Luciferase activity was normalized to total cell protein using a BCA protein assay kit (Uptima, Interchim 
SA, Montluçon, France), and expressed as relative light units (RLU) per mg of protein. Data are presented as means and standard deviation (s.d.) based on three independent experiments, each in duplicate for the determination of the RLU and in triplicate for protein quantification.

\subsection{Cytotoxicity.}

MTT assays were performed to determine the toxicity of polyplexes as well as polymers. $48 \mathrm{~h}$ after transfection, $50 \mu \mathrm{L}$ of MTT (3-(4,5-dimethylthiazol-2-yl)-2,5-diphenyltetrazolium bromide; $5 \mathrm{mg} / \mathrm{ml}$ in PBS) was added to each well and the cells were incubated for $4 \mathrm{~h}$ at $37^{\circ} \mathrm{C}$. The medium was taken of and the cells were washed with PBS $(500 \mu \mathrm{L})$. Then acidified isopropanol $(1 \mathrm{~mL})$ and a solution at SDS $3 \%(200 \mu \mathrm{l})$ were added. MTT was thus converted in water-soluble formazan. The absorbance was measured at $560 \mathrm{~nm}$ with a Victor I spectrophotometer and expressed as a percentage of the absorbance of non-transfected cells. Data are presented as mean and standard deviation (s.d.) based on two independent experiments, each in triplicate.

\subsection{Flow cytometry experiments.}

After $48 \mathrm{~h}$, transfected cells were washed two times with PBS, harvested by trypsin, centrifuged (1500 rpm for $5 \mathrm{~min}$ at $\left.4^{\circ} \mathrm{C}\right)$ and suspended in PBS. The cell-associated fluorescence intensity was measured by flow cytometry (LSR, Becton Dickinson). The cellassociated fluorescence was recorded at $520 \mathrm{~nm}$ after excitation at $488 \mathrm{~nm}$ and was expressed as the mean fluorescence intensity $(\mathrm{MFI})$ of $1 \times 10^{4}$ cells.

\subsection{Confocal laser scanning microscopy (CLSM).}

HeLa cells were seeded two days prior to the experiments, at a density of $1.4 \times 10^{4}$ cells in 0.5 $\mathrm{mL}$ culture medium per well in a 4-well Lab-Teck chambered coverglass (Nunc, Dutsher 
S.A., Brumath, France). Cells were transfected with polyplexes containing pCMV-EGFP. After 48h, confocal microscopy analysis was performed using Zeiss Axiovert 200M inverted microscope (equipped with a Plan-Apochromat $63 x$ objective, NA $=1.4$ ) coupled with Zeiss LSM 510 scanning confocal head (Carl Zeiss Co., Ltd., Jena, Germany).

\section{Results and discussion}

\subsection{Synthesis of primary and secondary polyvinylamines}

Following recently reported procedures, ${ }^{35,46}$ a series of polyvinylamines (PVAm) and poly $(N$ methylvinylamines) (PMVAm) was prepared by FRP or OMRP of $N$-vinylacetamide (NVA) or $N$-methylvinylacetamide (NMVA) followed by the acidic hydrolysis of the pendant amide functions of the poly(vinylacetamide)s (Figure 1, route B). The synthesis of these primary and secondary polyvinylamine derivatives is commented below and their macromolecular characteristics are presented in Tables 1 and 2. For the sake of clarity, an abbreviated polymer terminology was used. PN and PM stand for PVAm and PMVAm, respectively. The following number refers to the number-average degree of polymerization $\left(D P_{\mathrm{n}}\right)$. Behind it, the polymerization method is designated by $\mathrm{F}$ and $\mathrm{C}$, for free and controlled cobalt-mediated radical polymerization, respectively. The final letter provides information on the hydrolysis conditions: s for soft $(\mathrm{HCl} 2 \mathrm{~N}), \mathrm{m}$ for moderate $(\mathrm{HCl} 3 \mathrm{~N})$ and h for harsh $(\mathrm{HCl} 6 \mathrm{~N})$. For more precision, the deacetylation degree of some polymers is indicated at the end of the abbreviated name. For instance, PM155-Fm23 designates a PMVAm with a degree of polymerization of 155 prepared by free radical polymerization and subsequent hydrolysis using $\mathrm{HCl} 3 \mathrm{~N}$ with $23 \%$ of hydrolysis.

Synthesis of poly(vinylacetamide) precursors: Poly(vinylacetamide) (PNVA) was first synthesized by FRP of NVA initiated by $\mathrm{V} 70$ at $30^{\circ} \mathrm{C}$. The resulting polymer was 
characterized by a molar mass of $58 \mathrm{~kg} / \mathrm{mol}\left(D P_{\mathrm{n}}=685\right)$ and a quite broad molar mass distribution $(\bigoplus=1.69)$ (Table 1 , entry 1$)$. Note that shorter polymers could not be obtained by FRP even when very high amounts of V70 were used probably due to the high reactivity of NVA. ${ }^{39}$ On the other hand, we prepared a series of PNVAs with various molar masses and a narrow molar mass distribution via photoinitiated OMRP of NVA using VA-086 as initiator and $\mathrm{Co}(\mathrm{acac})_{2}$ as controlling agent, as reported elsewhere. ${ }^{35}$ By varying the $[\mathrm{NVA}] /[\mathrm{VA}-$ 086]/[Co(acac $\left.)_{2}\right]$ ratio and the reaction time, five PNVAs were obtained with molar masses ranging from $13 \mathrm{~kg} / \mathrm{mol}\left(D P_{\mathrm{n}}=153\right)$ to $129 \mathrm{~kg} / \mathrm{mol}\left(D P_{\mathrm{n}}=1510\right)($ Table 1 , entries 2-6). The molar mass dispersity was low, i.e. between 1.06 and 1.27 , except for the PNVA with the highest molar mass $\left(M_{\mathrm{n}}=129 \mathrm{~kg} / \mathrm{mol}, D P_{\mathrm{n}}=1510\right.$, and $\left.Ð=1.56\right)$. Poly $(N-$ methylvinylacetamide)s (PNMVAs) were also prepared by FRP and OMRP. A set of four PNMVAs with a molar mass ranging from $9 \mathrm{~kg} / \mathrm{mol}$ to $28 \mathrm{~kg} / \mathrm{mol}$ and a molar mass distribution around 2 was obtained by FRP using different NMVA/V70 molar ratios (Table 1, entries 7-10). In addition, as previously reported, ${ }^{46}$ the controlled polymerization of NMVA was performed using an alkylcobalt complex as OMRP initiator at $40^{\circ} \mathrm{C}$ leading to welldefined PNMVAs with molar masses ranging from $11 \mathrm{~kg} / \mathrm{mol}$ to $67 \mathrm{~kg} / \mathrm{mol}$ (Table 1 , entries 11-14). Again, except for the sample with a highest degree of polymerization $\left(D P_{\mathrm{n}}=677\right)$, the molar mass distribution of the PNMVA samples were below 1.2 (Table 1, entry 14). 
Table 1. Characteristics of poly( $N$-vinylacetamides) (PNVA) and poly $(N$-methylvinylacetamides) (PNMVA) and the corresponding poly $(N$ vinylamines) (PVAm) and poly(N-methylvinylamines) (PMVAm) synthesized by FRP and OMRP followed by amide hydrolysis.

\begin{tabular}{|c|c|c|c|c|c|c|c|c|c|c|}
\hline \multirow{3}{*}{ Entry } & \multirow{3}{*}{ Name } & \multirow{3}{*}{ Polymer } & \multicolumn{4}{|c|}{ Poly(vinylacetamide)s } & \multicolumn{4}{|c|}{ Polyvinylamines } \\
\hline & & & \multirow[b]{2}{*}{ Synthesis } & \multirow{2}{*}{$\begin{array}{c}M_{\mathrm{n}}^{\mathrm{LS}} \\
(\mathrm{kg} / \mathrm{mol})^{\mathrm{g}}\end{array}$} & \multirow[b]{2}{*}{$D P_{\mathrm{n}}^{\mathrm{h}}$} & \multirow[b]{2}{*}{$\theta^{i}$} & \multirow[b]{2}{*}{$\begin{array}{c}\% \text { of } \\
\text { hydrolysis }^{k}\end{array}$} & \multicolumn{2}{|c|}{ Composition } & \multirow{2}{*}{$\underset{(\mathrm{kg} / \mathrm{mol})^{\mathrm{m}}}{M_{\mathrm{n}}}$} \\
\hline & & & & & & & & $\begin{array}{c}D P_{\mathrm{n}} \text { amine } \\
\left(\mathrm{n}^{\prime}\right)^{\prime}\end{array}$ & $\begin{array}{c}D P_{\mathrm{n}} \text { acetamide } \\
(\mathrm{n})^{\prime}\end{array}$ & \\
\hline 1 & PN700-Fs & $\mathrm{PVAm}^{\mathrm{a}, \mathrm{e}}$ & FRP & 58 & 685 & 1.69 & 94 & 644 & 41 & 31.2 \\
\hline 2 & PN150-Cs & & & 13 & 153 & 1.06 & 91 & 139 & 14 & 7.2 \\
\hline 3 & PN255-Cs & & & 22 & 256 & 1.14 & 88 & 233 & 23 & 12.0 \\
\hline 4 & PN660-Cs & PVAm $^{\mathrm{b}, \mathrm{e}}$ & OMRP & 56 & 662 & 1.18 & 90 & 596 & 66 & 31.2 \\
\hline 5 & PN940-Cs & & & 80 & 940 & 1.27 & 87 & 818 & 122 & 45.5 \\
\hline 6 & PN1510-Cs & & & 129 & 1510 & 1.56 & 92 & 1389 & 121 & 70.0 \\
\hline 7 & PM100-Fh & & & 9 & 93 & $2.02^{\top}$ & 78 & 73 & 20 & 6.2 \\
\hline 8 & PM140-Fh & PMVA $\mathrm{m}^{\mathrm{c}, \mathrm{f}}$ & & 14 & 138 & 1.79 & 81 & 112 & 26 & 9.0 \\
\hline 9 & PM165-Fh & PIVVAm & FRP & 16 & 164 & $1.99^{\mathrm{J}}$ & 88 & 144 & 20 & 10.2 \\
\hline 10 & PM285-Fh & & & 28 & 284 & $2.11^{\mathrm{J}}$ & 71 & 202 & 82 & 19.6 \\
\hline 11 & PM110-Ch & & & 11 & 107 & 1.08 & 82 & 88 & 19 & 6.9 \\
\hline 12 & PM265-Ch & PMVAm ${ }^{\mathrm{d}, \mathrm{f}}$ & OMRP & 26 & 265 & 1.14 & 87 & 230 & 35 & 16.6 \\
\hline 13 & PM310-Ch & PIVVAm & UMRP & 31 & 313 & 1.12 & 93 & 291 & 22 & 18.7 \\
\hline 14 & PM680-Ch & & & 67 & 677 & 2.02 & 91 & 616 & 61 & 41.1 \\
\hline
\end{tabular}

${ }^{a}$ Free Radical Polymerization of NVA, conditions $[\mathrm{NVA}] /[\mathrm{V} 70]=47$, in $\mathrm{MeOH}, \mathrm{NVA} / \mathrm{MeOH}=4 / 6$ w/v $\%$, $30^{\circ} \mathrm{C}$ for 45 min. ${ }^{\mathrm{b}}$ Organometallic Mediated Radical Polymerization of NVA with photo-initiation at $0^{\circ} \mathrm{C}$ for $4 \mathrm{~h}$ then polymerization at rt. Conditions are respectively for PN150-Cs, PN255-Cs, PN660-Cs, PN940-Cs and $\mathrm{PN} 1510-\mathrm{Cs}$, [NVA] $/[\mathrm{VA0} 66] /\left[\mathrm{Co}(\mathrm{acac})_{2}\right]=110 / 2 / 1$ for $2 \mathrm{~h}$ and $4 \mathrm{~h}$, [NVA]/[VA086]/[Co(acac) 2$]=220 / 2 / 1$ for $7.5 \mathrm{~h}$ and $6 \mathrm{~h}$ and $[\mathrm{NVA}] /[\mathrm{VA0} 66] /\left[\mathrm{Co}(\mathrm{acac})_{2}\right]=440 / 2 / 1 \mathrm{for}$ $7.5 \mathrm{~h} .{ }^{\mathrm{c}}$ Free Radical Polymerization of NMVA. Conditions for PM100-Fh, PM140-Fh, PM165-Fh and PM285-Fh are respectively [NMVA]/[V70] = 25, [NMVA]/[MeOH] = $1 / 1 \mathrm{v} / \mathrm{v} \%$, at $30^{\circ} \mathrm{C}$ for $23 \mathrm{~h},[\mathrm{NMVA}] /[\mathrm{V} 70]=100,[\mathrm{NMVA}] /[\mathrm{MeOH}]=1 / 1 \mathrm{v} / \mathrm{v} \%$, at $30^{\circ} \mathrm{C}$ for $4 \mathrm{~h},[\mathrm{NMVA}] /[\mathrm{V} 70]=51,[\mathrm{NMVA}] /[\mathrm{MeOH}]=1 / 1 \mathrm{v} / \mathrm{v} \%$, at $30^{\circ} \mathrm{C}$ for $14.5 \mathrm{~h}$ and $[\mathrm{NMVA}] /[\mathrm{V} 70]=100,[\mathrm{NMVA}] /[\mathrm{MeOH}]=1 / 1 \mathrm{v} / \mathrm{v} \%$, at $30^{\circ} \mathrm{C}$ for $22 \mathrm{~h}$. ${ }^{\mathrm{d}}$ Cobalt Mediated Radical Polymerization of NMVA. Conditions for PM110-Ch, PM265-Ch, PM310-Ch and PM680-Ch are respectively [NMVA]/[RCo] $=113,302,297$ and 538, in bulk at $40^{\circ} \mathrm{C}$ for $5 \mathrm{~h}, 20.5 \mathrm{~h}, 16 \mathrm{~h}$ and $48 \mathrm{~h} .{ }^{\mathrm{e}} \mathrm{Hydrolysis}$ performed with $\mathrm{HCl} 2 \mathrm{~N}$ at $120^{\circ} \mathrm{C}$, for $14 \mathrm{~h} .{ }^{\mathrm{f}}$ Hydrolysis performed with $\mathrm{HCl} 6 \mathrm{~N}$ at $120^{\circ} \mathrm{C}$ for $64 \mathrm{~h} .{ }^{\mathrm{g}}$ Determined by SEC in DMF equipped with a MALLS detector, dn/dc PNVA $=0.060$ and dn/dc PNMVA 
$=0.071 . \mathrm{LS}=$ light scattering. ${ }^{\mathrm{h}}$ Calculated using the following formula: $\mathrm{DP}_{\mathrm{n}}=M_{\mathrm{n}}{ }^{\mathrm{LS}} / \mathrm{MM}_{\text {monomer }}{ }^{\mathrm{i}}$ Determined by SEC in DMF using a PS calibration. ${ }^{\mathrm{j}}$ Determined by SEC in DMF at $60^{\circ} \mathrm{C}$ using a PMMA calibration using two PSS GRAM $1000 \AA$ columns $(8 \times 300 \mathrm{~mm}$; separation limits: $1-1000 \mathrm{~kg} / \mathrm{mol})$ and one PSS GRAM $30 \AA$ ( $8 \times 300 \mathrm{~mm}$; separation limits: $0.1-10 \mathrm{~kg} / \mathrm{mol}$ ). ${ }^{\mathrm{k}}$ Determined by elemental analysis (EA) (SI Table S1 for crude EA results and calculations). ${ }^{1} \mathrm{n}$ and $\mathrm{n}$ ' stand for the number of amides and amines after hydrolysis in the polymer backbone (cf. structure in Figure 1B). ${ }^{\mathrm{m}}$ Number-average molar mass calculated by the molar mass of the polyamide precursor and the level of hydrolysis of the amide moieties. 
Amide hydrolysis: The above prepared poly(vinylacetamide)s were then converted into the corresponding polyvinylamines by acidic hydrolysis of the acetamido groups (Table 1). The percentage of deacetylation was determined by comparing the $\mathrm{C} / \mathrm{N}$ ratio measured by $\mathrm{EA}$ in the polymer before and after acidic treatment (SI, Table S1).$^{39}$ The PNVA samples were hydrolyzed using conditions described by Akashi et al., ${ }^{39,47}$ i.e. $\mathrm{HCl} 2 \mathrm{~N}$ at $120^{\circ} \mathrm{C}$ for $14 \mathrm{~h}$, whereas harsher conditions were necessary for hydrolyzing the PNMVAs $\left(\mathrm{HCl} 6 \mathrm{~N}\right.$ at $120^{\circ} \mathrm{C}$ for $\left.64 \mathrm{~h}\right){ }^{39}$ Under these conditions, the percentage of deacetylation was $87-94 \%$ and $70-94 \%$ for PNVA and PNMVA, respectively. Typical ${ }^{1} \mathrm{H}$ NMR spectra of the resulting PVAm and PMVAm are provided in Figure S2 and confirm the low amount of residual acetamido groups along the backbone. A third hydrolysis condition, reported by Buys et al ${ }^{41}\left(\mathrm{HCl} 3 \mathrm{~N}\right.$ at $\left.100^{\circ} \mathrm{C}\right)$, was applied to a PNMVA sample prepared by FRP $\left(D P_{\mathrm{n}} 155\right)$ in order to prepare a series of $\mathrm{P}(\mathrm{MVAm}-\mathrm{co}-\mathrm{NMVA})$ containing different amounts of residual acetamido groups (Table 2). The acidic treatment was stopped at different reaction times and $23 \%$ to $94 \%$ hydrolysis was reached. As discussed later, these compounds allowed us to assess the possible effect of the residual acetyl groups on the transfection efficiency. Because these polymers are dedicated to a biomedical application, it is important to mention that cobalt was carefully removed from all polymers synthesized by OMRP. Indeed, after purification, less than $0.4 \mathrm{ppm}$ of Co was found in the polyvinylamines according to the inductively coupled plasma analysis. ${ }^{35}$

Table 2. Characteristics of P(NMVA-co-MVAm) copolymers obtained from PM155-F through partial deacetylation 


\begin{tabular}{|c|c|c|c|c|c|}
\hline \multirow[b]{2}{*}{ Entry } & \multirow[b]{2}{*}{ Polymer } & \multirow{2}{*}{$\begin{array}{c}\% \text { of } \\
\text { hydrolysis }^{a}\end{array}$} & \multicolumn{2}{|c|}{ Composition of P(NMVA-co-MVAm) } & \multirow{2}{*}{$\underset{(\mathrm{kg} / \mathrm{mol})}{M_{\mathrm{b}}}$} \\
\hline & & & $\begin{array}{c}D P_{\mathrm{n}} \text { amine } \\
\left(\mathrm{n}^{\prime}\right)\end{array}$ & $D P_{\mathrm{n}}$ acetamide $(\mathrm{n})$ & \\
\hline 1 & $\begin{array}{l}\text { PM155- } \\
\text { Fm23 }\end{array}$ & 23 & 36 & 119 & 27.7 \\
\hline 2 & $\begin{array}{l}\text { PM155- } \\
\text { Fm37 }\end{array}$ & 37 & 57 & 98 & 13.9 \\
\hline 3 & $\begin{array}{l}\text { PM155- } \\
\text { Fm44 }\end{array}$ & 44 & 68 & 87 & 12.2 \\
\hline 4 & $\begin{array}{l}\text { PM155- } \\
\text { Fm54 }\end{array}$ & 54 & 84 & 71 & 11.8 \\
\hline 5 & $\begin{array}{l}\text { PM155- } \\
\text { Fm64 }\end{array}$ & 64 & 99 & 56 & 11.2 \\
\hline 6 & $\begin{array}{l}\text { PM155- } \\
\text { Fm76 }\end{array}$ & 76 & 120 & 35 & 10.3 \\
\hline 7 & $\begin{array}{l}\text { PM155- } \\
\text { Fm94 }\end{array}$ & 94 & 146 & 9 & 9.2 \\
\hline
\end{tabular}

The PM155-F precursor was obtained by Free Radical Polymerization of NMVA. Conditions: [NMVA]/[V70] $=51$, in bulk, at $30^{\circ} \mathrm{C}$ for $19 \mathrm{~h} . M_{\mathrm{n}}{ }^{\mathrm{LS}}=15500, D=1.55{ }^{a}{ }^{a}$ Hydrolysis conditions performed with $\mathrm{HCl} 3 \mathrm{~N}$ at $100^{\circ} \mathrm{C}$, for different times. ${ }^{\mathrm{b}}$ Number-average molar mass calculated by the molar mass of the precursor and the level of hydrolysis of the amide moieties.

\subsection{Polyplexes formation and characterization}

Polyplexes were formed in $10 \mathrm{mM}$ HEPES buffer, $\mathrm{pH}$ 7.4. The amount of polymer necessary to allow complete pDNA condensation (corresponding to ratio 1 in the following Figures, and to the lowest ratio reported in Table 3) was determined by agarose gel retardation assays upon electrophoresis of polyplexes made with increasing amounts of polymer (Figure S3). In contrast to free pDNA, no migration was observed when pDNA was condensed with the polyvinylamine derivatives, e.g. PN255-Cs, PN700-Fs, PM310-Ch or PM155-Fm76 (in Figure S3), suggesting the proper complexation of the nucleic acid.

Table 3 reports for each polymer the lowest polymer/pDNA weight ratios (WR) (ratio 1) allowing complete pDNA condensation and a second one (ratio 2) made with twofold amount of 
polymer. For both types of polyvinylamines (the primary and secondary one) the ratio 1 was generally 1 and 3, excepted for the shortest PVAm (PN-C150) for which higher amounts of polymer were needed ( $\mathrm{WR}=4$ and 8 ). The polymer/pDNA weight ratios (WR) can be translated into the nitrogen/phosphate $(\mathrm{N} / \mathrm{P})$ molar ratio, which relates the number of protonable nitrogen atoms $(\mathrm{N})$ needed to complex efficiently one phosphate group (P) of the pDNA (see experimental section for calculations). In all cases, an excess of protonable amines was necessary to achieve the pDNA condensation. Moreover, less protonable nitrogens were necessary to reach the complete condensation of pDNA with PMVAm (N/P charge ratio from 4 to 9) as compared to PVAm (6 to 25). This suggests that secondary amines are more efficient to condense the pDNA than primary amine, at least for this class of cationic polymer. It is well known that a small size and a positive charge are essential parameters for an efficient gene carrier: positively charged polyplexes interact easily with the negatively charged cell membranes through electrostatic interactions, and the uptake by the cells is favoured for small polyplexes. ${ }^{48-57}$ Most of the PVAm or PMVAm-based polyplexes had a hydrodynamic diameter ranging from 100 to $300 \mathrm{~nm}$ and $\zeta$-potentials ranging from +15 to $+55 \mathrm{mV}$ (Table 3 ).

Table 3. Characterization of PVAm and PMVAm polyplexes. 


\begin{tabular}{|c|c|c|c|c|c|}
\hline Entry & Polyplexes & $\begin{array}{c}\text { polymer/pDN } \\
\text { A }^{a} \\
\text { WR }^{a}\end{array}$ & $N / P^{b}$ & $\begin{array}{c}D_{h}^{c} \\
(n m)\end{array}$ & $\zeta_{(m V)}^{d}$ \\
\hline \multirow{2}{*}{1} & \multirow{2}{*}{ PN700-Fs-plex } & 1 & 7 & 310 & +26 \\
\hline & & 3 & 21 & 200 & +42 \\
\hline \multirow{2}{*}{2} & \multirow{2}{*}{ PN150-Cs-plex } & 4 & 25 & 140 & +50 \\
\hline & & 8 & 50 & 190 & +42 \\
\hline \multirow{2}{*}{3} & \multirow{2}{*}{ PN255-Cs-plex } & 1 & 6 & 180 & +48 \\
\hline & & 3 & 18 & 190 & +48 \\
\hline \multirow{2}{*}{4} & \multirow{2}{*}{ PN660-Cs-plex } & 1 & 6 & 99 & +26 \\
\hline & & 3 & 18 & 200 & +41 \\
\hline \multirow{2}{*}{5} & \multirow{2}{*}{ PN940-Cs-plex } & 1 & 6 & 260 & +50 \\
\hline & & 3 & 18 & 190 & +42 \\
\hline \multirow{2}{*}{6} & PN1510-Cs- & 1 & 6 & 230 & +54 \\
\hline & plex & 3 & 20 & 260 & +52 \\
\hline \multirow[b]{2}{*}{7} & PM100-Fh- & 1 & 4 & 150 & +32 \\
\hline & plex & 3 & 11 & 160 & +17 \\
\hline \multirow{3}{*}{8} & \multirow{3}{*}{$\begin{array}{l}\text { PM140-Fh- } \\
\text { plex }\end{array}$} & $1^{\mathrm{e}}$ & 4 & 1521 & +32 \\
\hline & & 3 & 12 & 230 & +42 \\
\hline & & 6 & 24 & 132 & +23 \\
\hline \multirow{2}{*}{9} & PM165-Fh- & 1 & 4 & 140 & +45 \\
\hline & plex & 3 & 14 & 100 & +32 \\
\hline \multirow{2}{*}{10} & PM285-Fh- & 2 & 7 & 130 & +32 \\
\hline & plex & 4 & 13 & 150 & +33 \\
\hline \multirow{2}{*}{11} & PM110-Ch- & 1 & 4 & 190 & +36 \\
\hline & plex & 3 & 12 & 150 & +39 \\
\hline \multirow{2}{*}{12} & PM265-Ch- & 2 & 9 & 130 & +47 \\
\hline & plex & 4 & 18 & 130 & +47 \\
\hline \multirow{3}{*}{13} & \multirow{3}{*}{$\begin{array}{l}\text { PM310-Ch- } \\
\text { plex }\end{array}$} & $1^{e}$ & 5 & 170 & +42 \\
\hline & & 3 & 15 & 220 & +32 \\
\hline & & 6 & 30 & 140 & +42 \\
\hline \multirow{2}{*}{14} & PM680-Ch- & 1 & 5 & 136 & +22 \\
\hline & plex & 3 & 15 & 140 & +32 \\
\hline \multirow{2}{*}{15} & \multirow{2}{*}{ 1PEI } & 2 & 1 & 130 & +48 \\
\hline & & 3 & 2 & 120 & +42 \\
\hline
\end{tabular}

${ }^{a} \mathrm{WR}=$ polymer/pDNA weight ratio. ${ }^{\mathrm{b}}$ amine/phosphate molar ratio calculated as described in experimental part. ${ }^{\mathrm{c}}$ Hydrodynamic diameters $\mathrm{D}_{\mathrm{h}}$ of the polyplexes at $298 \mathrm{~K}$ in HEPES $10 \mathrm{mM}, \mathrm{pH}$ 7.4. ${ }^{\mathrm{d}} \zeta$ potential of polyplexes at 298K in HEPES $10 \mathrm{mM}, \mathrm{pH} 7.4$. $^{\mathrm{e}}$ Transfection efficiency and cytotoxicity not evaluated at this WR.

Polyplexes were also prepared by complexing pDNA with PMVAm obtained by partial hydrolysis of PNMVA $\left(D P_{\mathrm{n}}=155, \mathrm{PM} 155-\mathrm{F}\right)$ thus containing different amounts of residual 
acetamido groups (Table 4). Gel retardation assays showed that higher quantities of polymer were necessary to condense pDNA with poorly deacetylated polymers, as expected (Figure S3, for PM155-Fm76 and PM155-Fm23). In all cases, positively charged complexes were again formed. However, at constant degree of polymerization, we observed a dependency of the polyplexes size on the polymer hydrolysis rate. Indeed, polymers with lower amine content, i.e. resulting from lower deacetylation degrees, usually produced bigger complexes. For example, the formation of large aggregates with a diameter superior to $5 \mu \mathrm{m}$ was notably observed for PM155-Fm23, PM155-Fm37 and PM155-Fm54.

Table 4. Characteristics of polyplexes prepared with increasingly hydrolysed PNMVA.

\begin{tabular}{cccccc} 
Entry & Polyplexes & $\begin{array}{c}\text { polymer/pDNA } \\
\mathbf{W R}^{\mathbf{a}}\end{array}$ & $\mathbf{N} / \mathbf{P}^{\mathbf{b}}$ & $\begin{array}{c}\mathbf{D}_{\mathbf{h}} \mathbf{c}^{\mathbf{c}} \\
\mathbf{( n m} \mathbf{)}\end{array}$ & $\begin{array}{c}\boldsymbol{\zeta}^{\mathbf{a}} \\
\mathbf{( m V} \mathbf{)}\end{array}$ \\
\hline \multirow{2}{*}{1} & PM155-Fm23- & 3 & 2.5 & 879 & +9 \\
& plex & 6 & 5 & 6316 & +1 \\
\hline \multirow{2}{*}{2} & PM155-Fm37- & 1 & 1.5 & $\mu^{\mathrm{e}}$ & +16 \\
& plex & 3 & 4 & 675 & +22 \\
\hline \multirow{2}{*}{3} & PM155-Fm44- & 2 & 5 & 1197 & +21 \\
& plex & 4 & 7 & 564 & +27 \\
\hline \multirow{2}{*}{4} & PM155-Fm54- & 1 & 2.3 & 5434 & +25 \\
& plex & 3 & 7 & 130 & +19 \\
\hline \multirow{2}{*}{5} & PM155-Fm64- & 1 & 3 & 237 & +23 \\
& plex & 3 & 8 & 136 & +23 \\
\hline \multirow{2}{*}{6} & PM155-Fm76- & 1 & 4 & 194 & +27 \\
& plex & 3 & 11 & 145 & +25 \\
\hline \multirow{2}{*}{7} & PM155-Fm94- & 1 & 5 & 391 & +31 \\
& plex & 3 & 15 & 148 & +30 \\
\hline
\end{tabular}

${ }^{\mathrm{a}}$ polymer/pDNA weight ratio. ${ }^{\mathrm{b}}$ amine/phosphate molar ratio calculated as described in experimental part. ${ }^{\mathrm{c}}$ hydrodynamic diameters $\mathrm{D}_{\mathrm{h}}$ of the polyplexes at $298 \mathrm{~K}$ in HEPES $10 \mathrm{mM}, \mathrm{pH} 7.4{ }^{\mathrm{d}} \zeta$ potential of polyplexes at $298 \mathrm{~K}$ in HEPES $10 \mathrm{mM}$, pH 7.4. ${ }^{\mathrm{e}}$ Out of range. 
On the other hand, the hydrodynamic diameter of almost all polyplexes formed with the less acetylated polymers, PM155-Fm64, PM155-Fm76, PM155-Fm94, was roughly between 150 and $250 \mathrm{~nm}$. Increasing the amount of amino groups along the backbone improves the polyplexes size reduction capacity for this polymer family. Because the transfection efficiency of a polyplex is notably affected by its size, it will be important to remember the differences in size when the performance of the polyvinylamine vectors with different amounts of residual acetamido groups will be evaluated in the next section.

\subsection{Polyvinyl amines as gene carriers}

Primary vs. secondary polyvinylamines as gene carrier: The transfection efficiency and cytotoxicity of the polyvinylamines-based polyplexes were evaluated on HeLa cells at two WR (Figures 2 and 3). Linear polyethylenimine (IPEI) was used as reference. Transfection was carried out with pDNA (pTG11033) encoding the luciferase gene and the luciferase activity was evaluated $48 \mathrm{~h}$ post-transfection.

In agreement with Wolfert et al, ${ }^{28}$ the primary polyvinylamine PN700-Fs $(\Xi=1.69)$ prepared by FRP showed low transfection efficiency, i.e. $10^{4} \mathrm{RLU} / \mathrm{mg}$ proteins (Figure 2A). Moreover, a similarly low efficiency was found for PN660-Cs, a PVAm of comparable molar mass but prepared by OMRP and possessing therefore a much lower molar mass distribution $(\nexists=1.18)$. Consequently, the dispersity of PVAm is not a crucial parameter in contrast to the molar mass of the carrier. In contrast, for PVAms of lower molar masses obtained by OMRP, i.e. PN255-Cs and PN150-Cs much higher transfection efficiencies were measured. For example, the level of transfection achieved by PN150-Cs was almost comparable to the one recorded for $1 \mathrm{PEI}\left(10^{8} v s\right.$. 
$10^{9} \mathrm{RLU} / \mathrm{mg}$ proteins, respectively). The dependency of the transfection performances on the degree of polymerization of PVAm is even clearer when comparing PN150-Cs to PN1510-Cs. The transfection increased by four order of magnitude (from $10^{4}$ to $10^{8} \mathrm{RLU} / \mathrm{mg}$ proteins) when the chain length of the polymer was divided by ten.
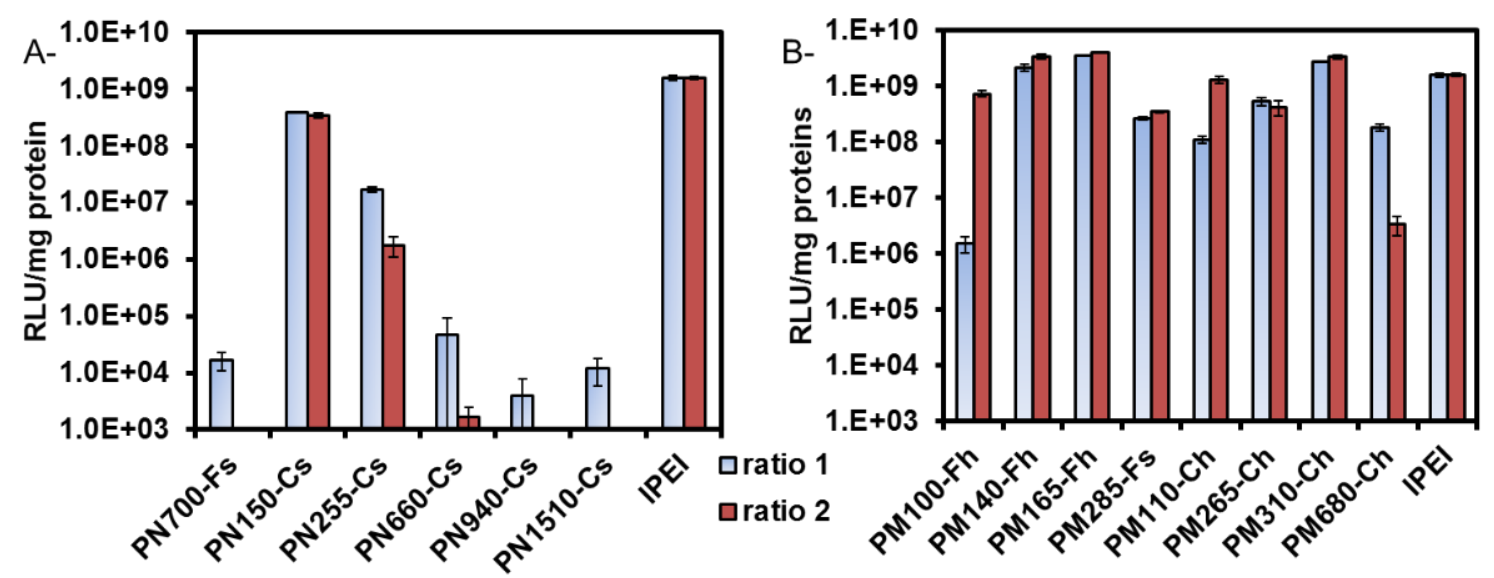

Figure 2. Transfection efficiency of HeLa cells. Cells were transfected with (A) PVAm and (B) with PMVAm polyplexes at two polymer/pDNA ratios (ratio 1 and ratio 2 correspond to the ratios reported in Table 3 using less and more polymer respectively). The luciferase activity was measured $48 \mathrm{~h}$ after the transfection and expressed as RLU/mg of protein.

This trend was somehow unexpected regarding the data reported by Wolfert et al. ${ }^{28}$ In this latter study, PVAm of three different molar masses $(3,8$ and $60 \mathrm{~kg} / \mathrm{mol})$ were produced by alkaline hydrolysis of polyvinylformamide (PNVF) ${ }^{28,} 58$ They showed poor transfection efficiencies for pDNA encoding for $\beta$-galactosidase (three order of magnitude lower than formulations using poly(L-)lysine). In their study, the effect of the molar mass on gene transfection was strictly 
opposite to our observations, i.e. best performances were reported for the highest molar mass polymers. Although it is not easy to fully rationalize this discrepancy, some hypotheses can be formulated. First, Wolfert used a different plasmid (pDNA of $6 \mathrm{~kb}$ coding for $\beta$-galactosidase) and a N/P molar ratio of 2 leading to large and almost neutral polyplexes $(\zeta=-1$ or $-2 \mathrm{mV})$. In our study, we used a N/P molar ratio superior to 6 , meaning that higher amounts of polymer were involved in the polyplex formation, which results in polyplexes with a positive surface charge $(\zeta$ $=+26$ to $+54 \mathrm{mV}$ ) and hydrodynamic diameter between 150 and $260 \mathrm{~nm}$ (Table 2). Secondly, the PVAms were prepared by different routes, i.e. by alkaline hydrolysis of PNVF ${ }^{28,58}$ and acidic hydrolysis of PNVA (in this work) respectively. Consequently, the sets of PVAm differ by the nature and amount of residual amides along their backbones, and the effect of the latter on the transfection is unknown. A priori, no formamide groups remain after alkaline hydrolysis of $\mathrm{PNVF}^{58}$ whereas 5 to $9 \%$ of residual acetamido groups are present in the PVAms investigated here (Table 1).

The transfection efficiency of secondary polyvinylamines (PMVAm) was also evaluated (Figure 2B). In contrast to the PVAm polyplexes, no significant influence of the polymer molar mass was noticed with PMVAm. Indeed, almost all PMVAm-based polyplexes reached remarkable transfection efficiency, between $10^{8}$ and $10^{9}$ RLU/mg proteins whatever the PMVAm's degree of polymerization. In this series, three candidates slightly outperformed IPEI with a transfection efficiency above $10^{9} \mathrm{RLU} / \mathrm{mg}$ proteins, namely PM140-Fh, PM165-Fh and PM310-Ch. No difference in transfection was noticed for PMVAms produced by FRP (PM100/140/165/285-Fh) and OMRP (PM110/265/310/680-Ch). This is easily conceivable considering the low impact of the PMVAm's molar mass on transfection and the fact that polymers prepared by FRP and 
OMRP essentially differs by their molar mass dispersity $(\bigoplus<1.3$ and $\sim 2$ for OMRP and FRP, respectively).

Comparison of the transfection performance of PVAm and PMVAm possessing similar degrees of polymerization $\left(D P_{\mathrm{n}} \sim 150\right)$ and around $90 \%$ of hydrolysis, for example PN150-Cs and PM165-Fh, emphasizes the beneficial effect of the methyl substitution of the nitrogen in the repeating units, i.e. the presence of pendant secondary amino groups instead of primary amino groups along the polymer backbone. In the case of the secondary polyvinylamines, PMVAms, the transfection was actually improved by a factor of ten. The difference of transfection efficiency observed for primary and secondary polyvinylamines could result from differences in basicity and protonation rate at physiological $\mathrm{pH}$. Indeed, titration of PVAm and PMVAm samples (SI Figure S1A) allowed us to estimate their apparent $\mathrm{pKa}$ values to 10.6 and 12.4, respectively, which reveals a slightly stronger basicity of the secondary polyvinylamine compared to the primary polyvinylamine. For both polymers, quite high protonation degrees (0.74 for PVAm and 0.79 for PMVAm) were calculated at $\mathrm{pH} 7.4$ (SI Figure S1C). Note that the buffering capacity, that is the proton quantity required to decrease the $\mathrm{pH}$ by one unit between pH 6.5 and $\mathrm{pH} 7.5$, was surprisingly lower for PMVAm $(0.09 \mathrm{~mL})$ compared to PVAm $(0.13$ $\mathrm{mL}$ ) for comparable polymer weight concentration (SI Figure S1B). The endosomal release of polyplexes involving the PVAm may then be favoured, compared to polyplexes formulated with PMVAm. However, endosomal escape of the polyplexes may not be the limiting step in gene transfection using polyvinylamines. Other factors, such as the internal structure of the polyplexes or the strength of the complexes may affect the release of the pDNA in the cytosol, thus the efficiency of the gene delivery. 
In addition to high transfection efficiency, gene carriers should exhibit high viability. The cytotoxicity was determined by using the MTT assay after $48 \mathrm{~h}$ of transfection (Figure 3). The lower molar mass PVAms exhibiting the best transfecting performances also presented the highest cell viabilities (Figure 3A). For example, cell viability as high as $95 \%$ was measured for PN150-Cs which is much higher than that of IPEI for which cell viability barely reached $50 \%$. However, lower viabilities around 45-60\% were recorded for less performant PVAms with higher molar masses, e.g. PN940-Cs and PN1510-Cs.
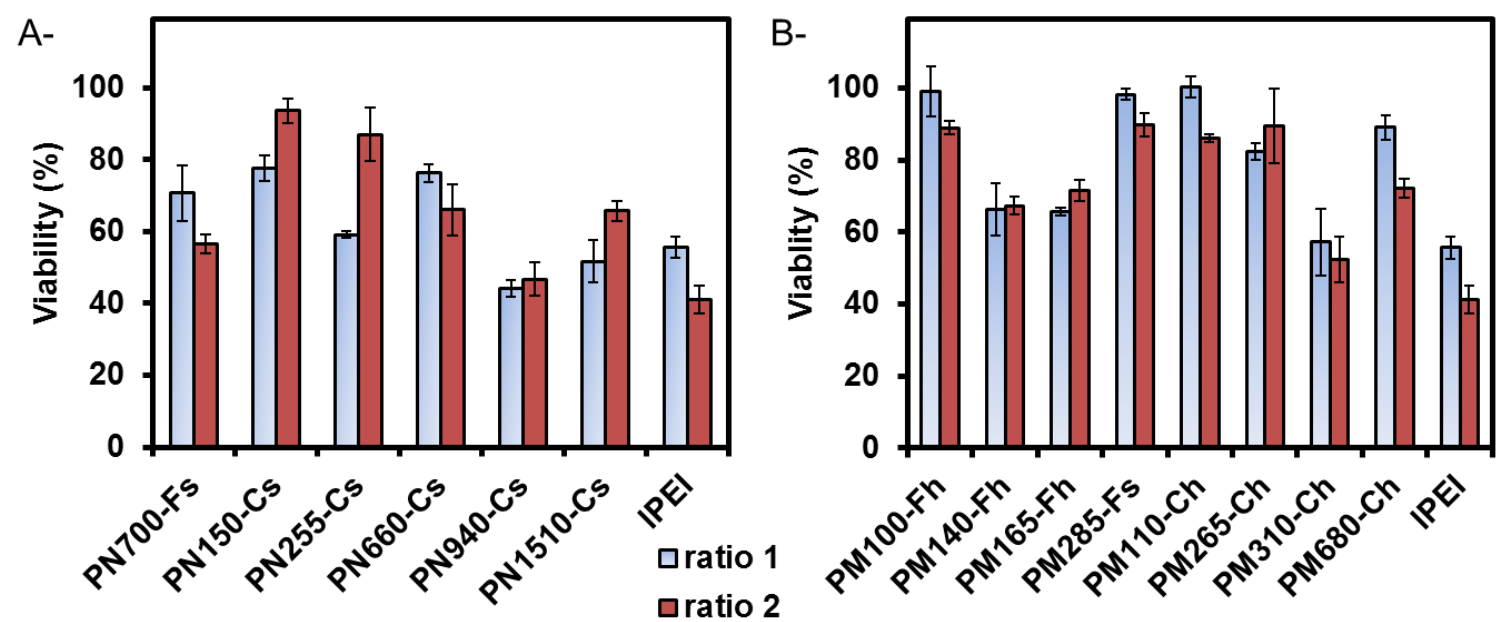

Figure 3. Viability of transfected HeLa cells. Transfection was performed with (A) PVAm polyplexes and (B) PMVAm polyplexes at two polymer/pDNA ratios (ratio 1 and ratio 2: lower and higher amount of polymer, Table 3). The cell viability was evaluated by MTT assay $48 \mathrm{~h}$ after transfection and expressed as percentage relative to untreated cells. 
On the other hand, all polyplexes formed with PMVAm showed higher cell viabilities (between 55 and $100 \%$ ) than with 1PEI (Figure 3B). In this series, however, PMVAms with the best transfection capacities (PM140-Fh, PM165-Fh and PM310-Ch) presented the lowest cell viabilities (between $55 \%$ and $70 \%$ ). Nevertheless, the other PMVAm polyplexes (e.g. PM285Fs, PM110-Ch and PM265-Ch), whose transfection abilities are still valuable, showed excellent cell viabilities between 90 and $100 \%$.

Finally, it should be noted that no significant differences in toxicity for polymers synthesized by either free radical polymerization or Co-mediated OMRP were observed; meaning that, after purification, the amount of Co (determined to be $<0.4 \mathrm{ppm}$ ) in the polymers is below the critical limit of toxicity.

Importance of the percentage of hydrolysis and of residual acetamido groups: The presence of acetamido groups in the polymer may play a role in both the transfection efficiency and cell viability. Indeed, it has been reported that the introduction of functional pendant moieties to a cationic polymer can modify the internal structure of the polyplex from an organized supramolecular structure to a loose amorphous organization with a weaker binding energy between the partners, facilitating the pDNA release in the cell and the transfection efficacy. Such an effect has already been described for $1 \mathrm{PEI}$ and its histidinylated derivative. ${ }^{59}$ For this reason, we explored the gene carrier performances of the series of PMVAm containing different amounts of residual acetamido groups prepared from partial hydrolysis of PNMVA (from $23 \%$ to $94 \%$ of hydrolysis). Figure 4A clearly shows that acetamido-rich polymers, obtained after short 
hydrolysis times (degrees of hydrolysis $<50 \%$ ), namely PM155-Fm23, PM155-Fm37 and PM155-Fm44, led to low transfection levels ( $\sim 10^{5} \mathrm{RLU} / \mathrm{mg}$ proteins).
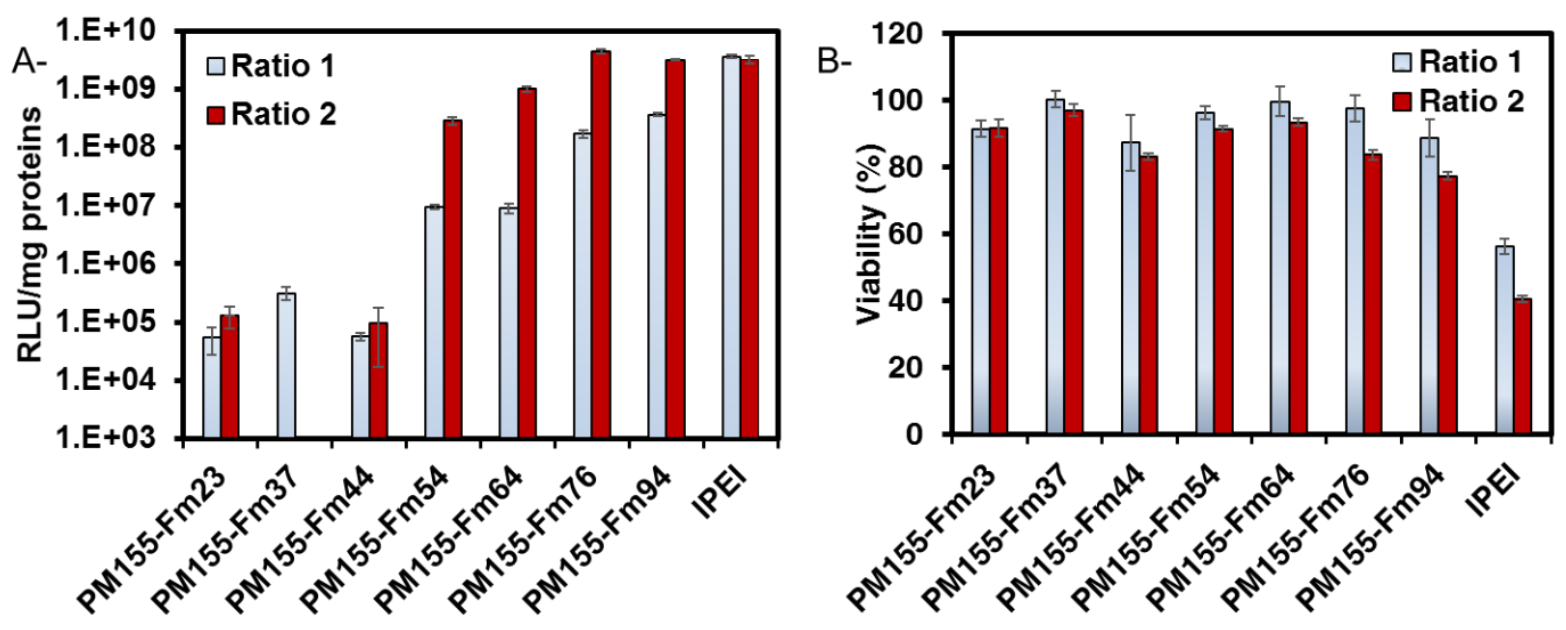

Figure 4. (A) Transfection efficiency and (B) cell viability of HeLa cells. Transfection was performed with increasingly hydrolyzed PMVAm polyplexes at two polymer/pDNA ratios (ratio 1 and ratio 2: lower and higher amount of polymer, cf. Table 4, WR). The luciferase activity was measured $48 \mathrm{~h}$ after the transfection and expressed as RLU/mg of protein. The cell viability was evaluated by MTT assay $48 \mathrm{~h}$ after transfection and expressed as percentage relative to untreated cells.

In contrast, amino-rich polymers, containing more than $70 \%$ of amines, like PM155-Fm76 and PM155-Fm94, presented high transfection efficiencies ( $\sim 10^{9} \mathrm{RLU} / \mathrm{mg}$ proteins). One can thus conclude that the residual acetamido groups within PMVAm should not exceed $30 \%$ for preserving the transfection capacities of the carrier. Note that the loss of efficiency of the 
acetamido-rich polymer was somewhat expected considering the very large size of the resulting polyplexes and the formation of large aggregates $\left(D_{h}>1 \mu \mathrm{m}\right)$ (Table 4). Finally, Figure 4B indicates that the cell viability was not affected by the composition of the amount of the residual acetamido groups.

Even if we demonstrated that the system tolerates between 6 and $30 \%$ of residual acetamido groups without loss of transfection efficiency, it remains still unclear whether the latter are beneficial or not. To answer this question, polyvinylamine free of acetyl groups should be prepared and tested. Such PMVAm are not accessible because they are exclusively obtained from PNMVA ( $c f$. Figure 1, route B) and complete deacetylation of the amide functions has never been achieved so far. However, well-defined acetyl-free PVAm can be prepared via RAFT polymerization of $N$-vinylphthalimide followed by the complete hydrazinolysis of the phthalimide groups of the PNVPi precursor (Figure 1, route A) ${ }^{27}$ Following this approach, we synthesized three PVAm with various degrees of polymerization, i.e. 55, 170 and 200 (SI, Table S2). Hydrazinolysis was successfully achieved leading to polymers exclusively composed of pendant amines. Positively charged polyplexes were then prepared with these compounds (SI Table S3) and tested in the pDNA transfection of and cell viability of HeLa cells (SI Figure S4).

Compared to IPEI the transfection efficiency of the acetyl-free PVAms was lower in all cases. Moreover, in spite of their similar degree of polymerization, the level of transfection observed for PN170-R obtained by RAFT $\left(10^{6}-10^{7} \mathrm{RLU} / \mathrm{mg}\right.$ proteins, depending on the WR, Figure $\left.5 \mathrm{~A}\right)$ was significantly lower than with PN150-Cs synthesized by OMRP which possessed $9 \%$ of residual acetamides $\left(10^{8} \mathrm{RLU} / \mathrm{mg}\right.$ proteins, Figure $\left.2 \mathrm{~A}\right)$. Similar to OMRP derived PVAm series, excellent cell viabilities were measured with PVAms prepared by RAFT (between 80 to $100 \%$ ) (much better than with 1PEI). These observations highlight the importance and especially the 
positive impact of the residual acetamido groups present in polyvinylamines obtained by deacetylation of a poly(vinylacetamides).

As a final confirmation of the beneficial effect of the pendant amides along the polyvinylamine backbone, PN170-R was acetylated at $50 \%$ (named PN170-R-OAc, Table S3, entry 2') and tested. Interestingly, the transfection efficiency was improved by more than one order of magnitude (till $10^{9} \mathrm{RLU} / \mathrm{mg}$ proteins) (SI Figure S4), close to that of IPEI.
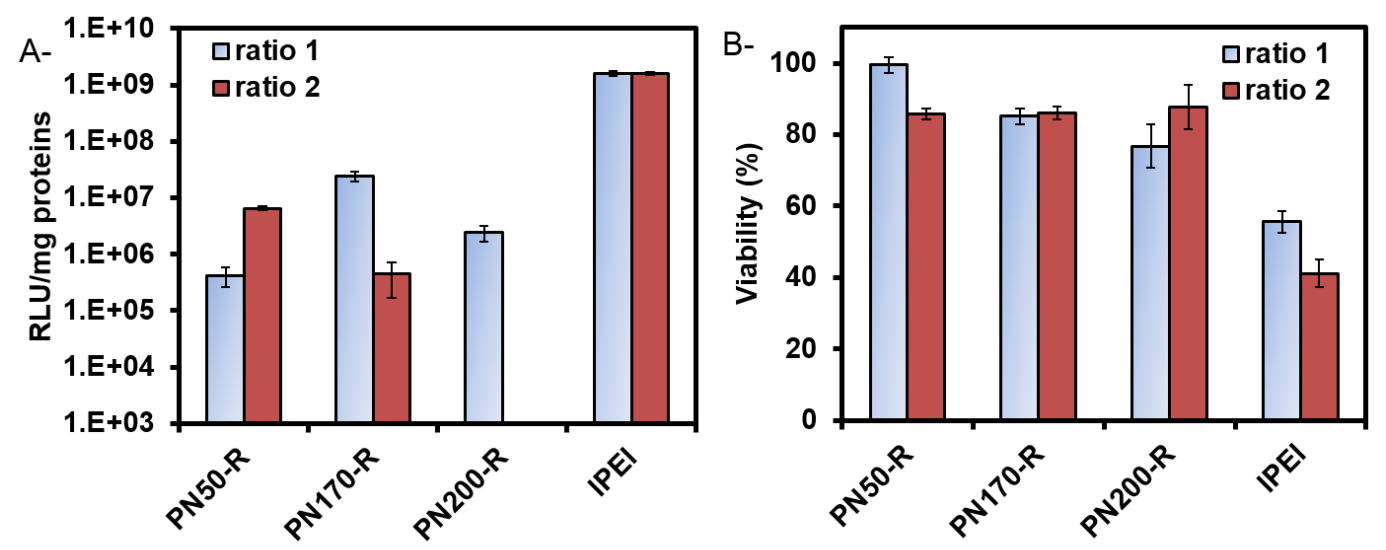

Figure 5. (A) Transfection efficiency and (B) cell viability of HeLa cells. Transfection was performed with PVAm (made by RAFT) polyplexes at two polymer/pDNA ratios (ratio 1 and ratio 2: lower and higher amount of polymer, Table S3). The luciferase activity was measured 48 $\mathrm{h}$ after the transfection and expressed as RLU/mg of protein. The cell viability was evaluated by MTT assay $48 \mathrm{~h}$ after transfection and expressed as percentage relative to untreated cells.

\subsection{Transfection efficiency and cell viability on other cell lines}


Polyvinylamines showing the best transfection efficiency on Hela cells, i.e. the secondary PM310-Ch and PM140-Fh, were tested on other cell lines (Figure 6). Skeletal muscle (H2K2B4 and $\mathrm{C} 2 \mathrm{C} 12)$, pulmonary (16HBE) and dendritic (DC2.4) cells were selected for their interest in gene transfer in relevant cellular models for Duchenne Muscular Dystrophy (DMD), cystic fibrosis and vaccination, respectively. Both PM310-Ch and PM140-Fh transfected the H2K2B4 cells less efficiently than 1PEI ( $10^{6} v s .10^{8}$ RLU/mg proteins). The transfection efficiency was also lower for 16HBE cells when using PM140-Fh instead of 1PEI. However, for all other cases, PMVAms and IPEI showed quite similar efficiencies (Figure 6A). On the other hand, the cell viability with $1 \mathrm{PEI}$ polyplexes was dramatically low: $50 \%, 30 \%, 30 \%$ and $10 \%$ for $\mathrm{H} 2 \mathrm{~K} 2 \mathrm{~B} 4$, $\mathrm{C} 2 \mathrm{C} 12,16 \mathrm{HBE}$ and DC2.4 cells, respectively (Figure 6B). ${ }^{19},{ }^{60}$ In this respect, PM310-Ch and PM140-Fh offered much higher cell viability than 1PEI, making them attractive alternative gene carriers. Noteworthy, PM140-Fh polyplexes demonstrated excellent constant cell viability close to $100 \%$ on all cell lines.
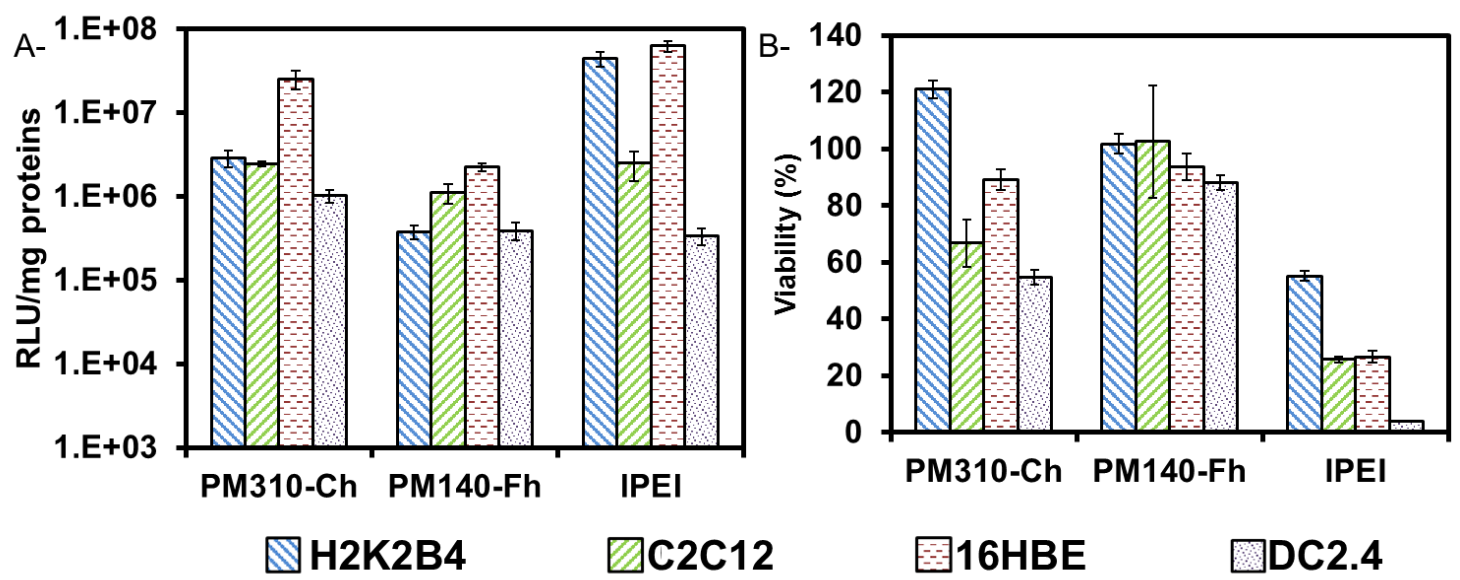
Figure 6. (A) Transfection efficiency and (B) cell viability of different cells lines. H2K2B4, C2C12, 16HBE and DC2.4 cells were transfected with the polyplexes made with PM310-Ch $(\mathrm{N} / \mathrm{P}=6), \mathrm{PM} 140-\mathrm{Fh}(\mathrm{N} / \mathrm{P}=3)$ and $\mathrm{PEI}(\mathrm{N} / \mathrm{P}=3)$. The luciferase activity was measured $48 \mathrm{~h}$ after the transfection and expressed as RLU/mg of protein. The cell viability was evaluated by MTT assay $48 \mathrm{~h}$ after transfection and expressed as percent to untreated cells.

Finally, PM140-Fh was further investigated for transfecting HeLa, C2C12, DC2.4 cells and fibroblasts with a plasmid DNA encoding for EGFP (SI Figure S5). Phase contrast images showed nice regular shape, whatever the cell line. No cytotoxicity was observed. The transfection of EGFP in the various cell lines was evidenced by the green fluorescence of the cell cytoplasm, which is the visible sign of the successful gene expression. Furthermore, the fluorescence/phase contrasts image overlay tends to demonstrate that the transfection occurs without any damage to the cells. No effect of the WR ratio could be noticed by this experiment.

\section{Conclusion}

Motivated by the recent advances in controlled radical polymerization giving access to welldefined polyvinylamine derivatives, we explored in details the potential of this class of disregarded polymers in gene transfection. For this purpose, a library of primary polyvinylamines (PVAm) and secondary poly( $N$-methylvinylamines) (PMVAm) with various molar masses and dispersities was prepared by free radical polymerization and organometallic- 
mediated radical polymerization of the corresponding $\mathrm{N}$-vinylacetamides followed by the acidic hydrolysis of the pendant amides. The transfection efficiency of pDNA/PVAm polyplexes on HeLa cells was found strongly dependent on the molar mass of PVAm. Only low molar mass PVAms synthesized by OMRP showed good transfection efficiencies, approaching the performance of 1PEI ( $10^{9} \mathrm{RLU} / \mathrm{mg}$ proteins). In contrast, all PMVAm samples presented high transfection efficiencies $\left(10^{8}-10^{9} \mathrm{RLU} / \mathrm{mg}\right.$ proteins) whatever the synthesis route (FRP or OMRP) and the degree of polymerization, at least for $D P_{\mathrm{n}}$ comprised between 100 and 700 . While OMRP appeared to be a necessary tool for designing PVAm with low molar masses ensuring considerable transfection levels, FRP, which is much easier to implement than OMRP, should be privileged for the preparation of the PMVAm carriers. Interestingly, in most cases, the cell viabilities were higher with both primary and secondary polyvinylamines compared to $1 \mathrm{PEI}$, which constitutes a major advantage over the latter. The beneficial effect of a few percent of residual acetamido groups along the polyvinylamine backbone, resulting from the partial deacetylation upon hydrolysis, was also clearly demonstrated. Nevertheless, a majority of pendant amines (>70\% in the case of PMVAm) was found necessary for the proper complexation of pDNA and transfection of HeLa cells. Finally, some PMVAm were successfully tested for the transfection of other cell lines including skeletal muscle, pulmonary and dendritic cells.

Overall, this work highlights for the first time the real potential of polyvinylamines as gene carriers. Their good transfection efficiency and low toxicity could certainly be further improved in the future by fine adjustment of their structure to make them even more attractive DNA carriers.

\section{ASSOCIATED CONTENT}


Elemental analyses, titration curves, NMR spectra, electrophoresis retardation assays, detailed conditions synthesis of polyvinylamines, polyplexes characterization, transfection efficiency and cell viability tests, fluorescent confocal microscopy, are available free of charge on the ACS Publications website.

\section{ACKNOWLEDGMENT}

The authors are grateful to the European Community in the frame of the Erasmus Mundus International doctoral school IDSFunMat and to the Belgian Science Policy (PAI VII-05) for their financial support. A.D. is Research Associate of the FRS-FNRS. C.D. is FNRS Research

Director. The authors from Liege also belong to the Research Unit "Complex and Entangled Systems from Atoms to Material. We also thank the "Cytometry and Cell Imaging platform" P@CYFIC at CBM Orléans, Véronique Peyre (UPMC) for lending us the automated titrator and helpful discussion ${ }_{2}$ and Claire Troufflard (UPMC) for help in NMR characterization.

\section{REFERENCES}

(1) Friedmann, T.; Roblin, R. Science 1972, 175, 949-955.

(2) Bertrand, N.; Leroux, J.-C. Journal of Controlled Release 2012, 161, 152-163.

(3) Ibraheem, D.; Elaissari, A.; Fessi, H., Gene therapy and DNA delivery systems. International Journal of Pharmaceutics 2014, 459, 70-83.

(4) Günzburg, W. H.; Salmons, B. Molecular Medicine Today 1995, 1, 410-417. 
(5) Bessis, N.; Garcia-Cozar, F. J.; Boissier, M. C. Gene Therapy 2004, 11, S10-S17.

(6) Nagasaki, T.; Shinkai, S. Journal of Inclusion Phenomena and Macrocyclic Chemistry 2007, 58, 205-219.

(7) Nguyen, D. N.; Green, J. J.; Chan, J. M.; Langer, R.; Anderson, D. G. Advanced Materials 2009, 21, 847-867.

(8) Labhasetwar, V. Current Opinion in Biotechnology 2005, 16, 674-680.

(9) Kundu, P. P.; Sharma, V. Current Opinion in Solid State and Materials Science 2008, 12, 89-102.

(10) von Harpe, A.; Petersen, H.; Li, Y.; Kissel, T. Journal of Controlled Release 2000, 69, 309-322.

(11) Forrest, M. L.; Gabrielson, N.; Pack, D. W. Biotechnology and Bioengineering 2005, 89, 416-423.

(12) Pun, S. H.; Bellocq, N. C.; Liu, A.; Jensen, G.; Machemer, T.; Quijano, E.; Schluep, T.; Wen, S.; Engler, H.; Heidel, J.; Davis, M. E. Bioconjugate Chemistry 2004, 15, 831-840.

(13) Brissault, B.; Leborgne, C.; Guis, C.; Danos, O.; Cheradame, H.; Kichler, A. Bioconjugate Chemistry 2006, 17, 759-765.

(14) Oskuee, R. K.; Dehshahri, A.; Shier, W. T.; Ramezani, M. The Journal of Gene Medicine 2009, 11, 921-932. 
(15) Oskuee, R. K.; Philipp, A.; Dehshahri, A.; Wagner, E.; Ramezani, M. The Journal of Gene Medicine 2010, 12, 729-738.

(16) Kunath, K.; von Harpe, A.; Fischer, D.; Kissel, T. Journal of Controlled Release 2003, 88, 159-172.

(17) Bertrand, E.; Goncalves, C.; Billiet, L.; Gomez, J. P.; Pichon, C.; Cheradame, H.; Midoux, P.; Guégan, P. Chemical Communications 2011, 47, 12547-12549.

(18) Gabrielson, N. P.; Pack, D. W. Biomacromolecules 2006, 7, 2427-2435.

(19) Brissault, B.; Kichler, A.; Guis, C.; Leborgne, C.; Danos, O.; Cheradame, H. Bioconjugate Chemistry 2003, 14, 581-587.

(20) Nimesh, S.; Aggarwal, A.; Kumar, P.; Singh, Y.; Gupta, K. C.; Chandra, R. International Journal of Pharmaceutics 2007, 337, 265-274.

(21) Teo, P. Y.; Yang, C.; Hedrick, J. L.; Engler, A. C.; Coady, D. J.; Ghaem-Maghami, S.; George, A. J. T.; Yang, Y. Y. Biomaterials 2013, 34, 7971-7979.

(22) Boussif, O.; Lezoualc'h, F.; Zanta, M. A.; Mergny, M. D.; Scherman, D.; Demeneix, B.; Behr, J. P. Proceedings of the National Academy of Sciences 1995, 92, 7297-7301.

(23) Dufès, C.; Uchegbu, I. F.; Schätzlein, A. G. Advanced Drug Delivery Reviews 2005, 57, 2177-2202.

(24) Borchard, G. Advanced Drug Delivery Reviews 2001, 52, 145-150. 
(25) Chu, D. S. H.; Schellinger, J. G.; Shi, J.; Convertine, A. J.; Stayton, P. S.; Pun, S. H. Accounts of Chemical Research 2012, 45, 1089-1099.

(26) Gao, Y.; Huang, J.-Y.; O’Keeffe Ahern, J.; Cutlar, L.; Zhou, D.; Lin, F.-H.; Wang, W. Biomacromolecules 2016, 17, 3640-3647.

(27) Liu, S.; Gao, Y.; A, S.; Zhou, D.; Greiser, U.; Guo, T.; Guo, R.; Wang, W. ACS Biomaterials Science \& Engineering 2016.

(28) Wolfert, M. A.; Dash, P. R.; Nazarova, O.; Oupicky, D.; Seymour, L. W.; Smart, S.; Strohalm, J.; Ulbrich, K. Bioconjugate Chemistry 1999, 10, 993-1004.

(29) Liu, L.; Yang, Y.-L.; Wang, C.; Yao, Y.; Ma, Y.-Z.; Hou, S.; Feng, X.-Z. Colloids and Surfaces B: Biointerfaces 2010, 75, 230-238.

(30) Zhong, Z.; Feijen, J.; Lok, M. C.; Hennink, W. E.; Christensen, L. V.; Yockman, J. W.; Kim, Y.-H.; Kim, S. W. Biomacromolecules 2005, 6, 3440-3448.

(31) Newland, B.; Tai, H.; Zheng, Y.; Velasco, D.; Di Luca, A.; Howdle, S. M.; Alexander, C.; Wang, W.; Pandit, A. Chemical Communications 2010, 46, 4698-4700.

(32) Prevette, L. E.; Kodger, T. E.; Reineke, T. M.; Lynch, M. L. Langmuir 2007, 23, 97739784.

(33) Popielarski, S. R.; Mishra, S.; Davis, M. E. Bioconjugate Chemistry 2003, 14, 672-678.

(34) Maki, Y.; Mori, H.; Endo, T. Macromolecular Chemistry and Physics 2007, 208, 25892599. 
(35) Dréan, M.; Guégan, P.; Detrembleur, C.; Jérôme, C.; Rieger, J.; Debuigne, A. Macromolecules 2016, 49, 4817-4827.

(36) Debuigne, A.; Champouret, Y.; Jérôme, R.; Poli, R.; Detrembleur, C. Chemistry - A European Journal 2008, 14, 4046-4059.

(37) Colombani, O.; Lejeune, E.; Charbonneau, C.; Chassenieux, C.; Nicolai, T. The Journal of Physical Chemistry B 2012, 116, 7560-7565.

(38) Borukhov, I.; Andelman, D.; Borrega, R.; Cloitre, M.; Leibler, L.; Orland, H. The Journal of Physical Chemistry B 2000, 104, 11027-11034.

(39) Drean, M.; Guégan, P.; Jerome, C.; Rieger, J.; Debuigne, A. Polymer Chemistry 2016, 7 , 69-78.

(40) Debuigne, A.; Caille, J.-R.; Jérôme, R. Macromolecules 2005, 38, 5452-5458.

(41) Buys, H. C. W. M.; Vercauteren, F. F.; van Elven, A.; Tinnemans, A. H. A. Recueil des Travaux Chimiques des Pays-Bas 1989, 108, 123-127.

(42) Destarac, M.; Brochon, C.; Catala, J.-M.; Wilczewska, A.; Zard, S. Z. Macromolecular Chemistry and Physics 2002, 203, 2281-2289.

(43) Chikhaoui-Grioune, D.; Aqil, A.; Zalfen, A. M.; Benaboura, A.; Jérome, C. Journal of Applied Polymer Science 2010, 117, 1005-1012.

(44) Maki, Y.; Mori, H.; Endo, T. Macromolecular Chemistry and Physics 2010, 211, 45-56. 
(45) Kolbe, H. V. J.; Boussif, O.; Delair, T.; Veron, L. Transgene S.A., patent: WO 1999005183 A1

(46) Debuigne, A.; Morin, A. N.; Kermagoret, A.; Piette, Y.; Detrembleur, C.; Jérôme, C.; Poli, R. Chemistry - A European Journal 2012, 18, 12834-12844.

(47) Akashi, M.; Nakano, S.; Kishida, A. Journal of Polymer Science Part A: Polymer Chemistry 1996, 34, 301-303.

(48) Burke, P. A.; Pun, S. H.; Reineke, T. M. ACS Macro Letters 2013, 2, 928-934.

(49) Kwon, Y. J. Accounts of Chemical Research 2012, 45, 1077-1088.

(50) Haussecker, D. Journal of Controlled Release.

(51) Dean, D. A.; Gasiorowski, J. Z. Cold Spring Harbor Protocols 2011, 2011, top101.

(52) Thomas, M.; Klibanov, A. M. Appl Microbiol Biotechnol 2003, 62, 27-34.

(53) Jones, C. H.; Chen, C.-K.; Ravikrishnan, A.; Rane, S.; Pfeifer, B. A. Molecular Pharmaceutics 2013, 10, 4082-4098.

(54) Adil, M. M.; Erdman, Z. S.; Kokkoli, E. Langmuir 2014, 30, 3802-3810.

(55) Wytrwal, M.; Leduc, C.; Sarna, M.; Goncalves, C.; Kepczynski, M.; Midoux, P.; Nowakowska, M.; Pichon, C. International Journal of Pharmaceutics 2015, 478, 372-382.

(56) Díaz-Moscoso, A.; Vercauteren, D.; Rejman, J.; Benito, J. M.; Ortiz Mellet, C.; De Smedt, S. C.; Fernández, J. M. G. Journal of Controlled Release 2010, 143, 318-325. 
(57) Hess, G. T.; Humphries Iv, W. H.; Fay, N. C.; Payne, C. K. Biochimica et Biophysica Acta (BBA) - Molecular Cell Research 2007, 1773, 1583-1588.

(58) Gu, L.; Zhu, S.; Hrymak, A. N. Journal of Applied Polymer Science 2002, 86, 3412-3419.

(59) Maury, B.; Gonçalves, C.; Tresset, G.; Zeghal, M.; Cheradame, H.; Guégan, P.; Pichon, C.; Midoux, P. Biomaterials 2014, 35, 5977-5985.

(60) Saegusa, T.; Yamada, A.; Taoda, H.; Kobayashi, S. Macromolecules 1978, 11, 435-436. 